\title{
LA PERSONA JURÍDICA COMO NUEVO SUJETO PASIVO DEL PROCESO PENAL EN LOS ORDENAMIENTOS CHILENO Y ESPAÑOL*
}

\section{Ana María Neira Pena**}

RESUMEN: Tanto en Chile como en España se ha introducido recientemente un régimen de responsabilidad penal de las personas jurídicas que plantea muchos problemas, tanto en el plano sustantivo como en el procesal. El presente trabajo trata, desde una perspectiva comparada, algunas de las cuestiones problemáticas que surgen cuando una persona jurídica ocupa el lugar de sujeto pasivo en el marco de un proceso penal. En particular se estudia la condición en la que interviene la persona jurídica en dicho proceso penal, qué derechos procesales se le atribuyen y en concreto con qué alcance se le reconoce el derecho a no declarar, como instrumental del más genérico derecho de defensa. A continuación se intenta determinar cuál es el momento idóneo para formalizar la investigación o la imputación contra la persona jurídica para tratar de no retrasar indebidamente el nacimiento de su derecho de defensa. Por último, se tratará el tema de la representación de la persona jurídica en el proceso que, en vista de su falta de corporeidad necesita actuar en el marco del enjuiciamiento a través de una concreta persona física que declare en su nombre y ejercite el resto de las facultades autodefensivas que le corresponden a todo imputado.

PALABRAS CLAVE: Responsabilidad penal de las personas jurídicas proceso penal - imputación - representación - derecho de defensa.

\section{JURIDICAL PERSON AS A NEW CRIMINAL DEFENDANT IN THE CHILEAN AND SPANISH LEGAL SYSTEMS}

ABSTRACT: Both Chile and Spain have recently introduced a system of criminal liability of juridical persons that poses a number of problems, at substantive and procedural levels. The present work deals, from

Fecha de recepción: 29 de agosto de 2013.

Fecha de aceptación: 2 de diciembre de 2013.

** Investigadora predoctoral de la Universidade da Coruña (España). Licenciada en Derecho y Administración y Dirección de Empresas. Correo electrónico: ana.neira.pena@gmail.com 
a comparative perspective, with some of the problematic issues that arise when a juridical person occupies the place of defendant in the context of criminal proceedings. In particular we study the condition which involves the juridical person in the criminal process, which due process rights are attributed to it and, more particularly, to what extent it has the right to not testify as instrumental of the, more generic, right of defence. Then, it attempts to determine which is the ideal moment to formalize the imputation against the juridical person in order to try to not to unduly delay the birth of its right of defence. Finally, an attempt will be made to describe the subject of the juridical person's representation in proceedings that, due to its lack of corporeality, needs to act in the framework of the trial through a specific person to declare on its behalf and to exercise the rest of the defensive powers that correspond to every defendant.

KEY WORDS: Criminal liability of legal persons - criminal proceedings - imputation - representation - right of defence.

Sumario: Introducción. 1) El estatus de la persona juridica como parte pasiva del proceso penal. (2.1) ¿En qué condición interviene la persona juridica en el proceso? (2.2) ¿Qué derechos se le atribuyen a la persona juridica imputada? (2.3) En particular, la problemática del derecho a no declarar. 3) El momento de la imputación o de la formalización de la investigación frente a la persona juridica. 4) La representación de la persona juridica en el proceso penal. (4.1) La situación de conflicto de intereses entre el representante personalmente imputado y la persona juridica. (4.2) La determinación del representante de la persona jurídica en el proceso. Conclusiones. Bibliografía citada.

\section{INTRODUCCIÓN}

Frente al tradicional aforismo societas deliquere non potest la tendencia actual está cambiando radicalmente hacia un sistema de criminalización de las personas jurídicas, aunque los fundamentos y criterios de imputación de esa responsabilidad penal difieren de unos sistemas nacionales a otros. La creciente complejidad de las estructuras organizativas, que hoy en día se encuentran en el tráfico jurídico, ha dado lugar al abandono de la vigencia de la citada máxima que ha perdido la pugna contra la necesidad político-criminal de dar una respuesta a esta nueva realidad delictiva. Actualmente, gran parte de la delincuencia económica ${ }^{1}$, aunque

ECharri Casi, Fermín J. (2003) Sanciones a personas juridicas en el proceso penal: las consecuencias accesorias, Navarra: Aranzadi, p. 23, señala que una muestra empírica del Instituto 
no exclusivamente esta, se comete a través de complejas redes societarias con relaciones internas de poder que no siempre responden a una estructura jerárquica clara, y que obstaculizan o impiden la acción de la justicia, así como la determinación de responsabilidades dentro del entramado orgánico de la persona jurídica.

En los Convenios internacionales procedentes de la OCDE, la ONU o el Consejo de Europa, o en las Directivas o Decisiones marco de la UE aparece la necesidad de prever sanciones contra las personas jurídicas ${ }^{2}$. En este sentido, se puede afirmar que la adopción de un sistema de responsabilidad penal de las personas jurídicas en Espańa viene aconsejado o impulsado desde la Unión Europea, en ese marco de homogeneización y creación de un espacio de libertad, seguridad y justicia. Pero lo cierto es que la legislación comunitaria no ha obligado a que sea través del Derecho Penal el castigo de las conductas que se atribuyen a esa creación artificial del Derecho, que es la persona jurídica, sino que lo que se viene reclamando desde tales instancias supranacionales es, tan solo, la imposición de "penas efectivas, proporcionadas y disuasorias". Por tanto, sin exigir ineludiblemente el recurso al Derecho Penal, se reclama la eficacia de las sanciones contra los entes colectivos, en vista de su elevado potencial criminógeno. Del mismo modo, desde la OCDE se ha impulsado la introducción de sistemas de responsabilidad de las personas jurídicas, lo que ha llevado a instaurarlos en países como Chile, donde, al igual que en España, y en general, en los ordenamiento jurídicos del civil law, la máxima societas delinquere non potest contaba con una arraigada tradición. En este sentido, se ha afirmado que la consecuencia más significativa en materia penal de los esfuerzos de Chile por incorporarse a la OCDE ha sido la introducción de la responsabilidad penal de las personas jurídicas ${ }^{3}$, a través de la Ley No 20.393, de 2 de diciembre de 20094.

Por otra parte, un sector doctrinal ${ }^{5}$ ha llamado la atención sobre el hecho de que la introducción de la responsabilidad penal de las personas jurídicas responde más bien a la influencia del ordenamiento estadouni-

Max Planck de Friburgo sitúa en torno al 80\% el porcentaje de delitos económicos cometidos en el seno o bajo la cobertura de las personas jurídicas.

2 Arts. 8.1 y 9.1 Decisión Marco 2000/383/JAI; 2.1 y 3.1 Decisión Marco 2002/946/JAI ; 5.1 y 6.1 Decisión Marco 2003/568/JAI; 6.1 y 7.1 Decisión Marco 2004/68/JAI; 6.1 y 7.1 Decisión Marco 2004/757/JAI; 8.1 y 9.1 Decisión Marco 2005/222/JAI; 5.1 y 6.1 Decisión Marco 2005/667/JAI.

3 Hernández Basualto, Héctor (2010). "La introducción de la responsabilidad penal de las personas jurídicas en Chile”, Política Criminal, Vol. 5, no 9, julio 2010, pp. 207-236, p. 208. Disponible en: www.politicacriminal.cl/Vol_05/n_09/Vol5N9A5.pdf

4 Ley núm. 20.393, de 2 de diciembre de 2009, que establece la responsabilidad penal de las personas jurídicas en los delitos de lavado de activos, financiamiento del terrorismo y delitos de cohecho.

5 Sobre este particular ha incidido especialmente Nieto Martín, Adán (2007). “¿Americanización o europeización del derecho penal económico?”, Revista Penal, Vol. 19, enero de 
dense y que la misma comparte un origen común con otros supuestos de americanización del derecho como el buen gobierno corporativo, el derecho de los mercados financieros, el sistema de prevención de riesgos laborales, o las normas de organización y control que se derivan del blanqueo de capitales. Sea como fuere, lo cierto es que cada vez son más los Estados europeos e iberoamericanos que introducen en sus ordenamientos un régimen de responsabilidad penal de las personas jurídicas. Pero, no es menos cierto que esta tendencia encuentra importantes dificultades dogmáticas y prácticas, debido a que los sistemas penales y procesales propios de los países de civil law son esencialmente antropomórficos, y están pensados para la imputación penal y para el enjuiciamiento criminal de personas físicas. Lo novedoso y revolucionario del tema, tanto para el Derecho penal como para el Derecho procesal penal de los países de tradición continental, explica las divergencias entra las regulaciones más recientes.

Entre los nuevos partícipes en este derrumbamiento del principio societas delinquere non potest destacan, como ya se ha comentado, Espańa y Chile. En cuanto al primero de ellos, la regulación introducida por la Ley Orgánica 5/2010, de 22 de junio, por la que se modifica la Ley Orgánica 10/1995, de 23 de noviembre, del Código Penal (en adelante CP) introduce por primera vez, de forma clara y sin ambages, un verdadero sistema de responsabilidad penal de las personas jurídicas en el ordenamiento español, en el que antes solo se preveía, en el art. 129 CP, un listado de consecuencias jurídico-penales aplicables a las personas jurídicas denominadas consecuencias accesorias, cuya naturaleza jurídica era incierta ${ }^{6}$, así como también lo eran sus presupuestos de aplicación, ya que la regulación penal no dejaba claro si eran accesorias del delito ${ }^{7}$ o de la pena impuesta a la persona física $^{8}$, ni si tenían naturaleza punitiva o exclusivamente preventiva. Con la nueva regulación, se han establecido auténticas

2007, pp. 120-136; Nieto Martín, Adán (2008) La responsabilidad penal de las personas juridicas: esquema de un modelo de responsabilidad penal, Madrid: Iustel, p. 19.

$6 \quad$ Siendo calificadas, por algunos autores, como medidas de seguridad (entre otros, EcharRI CASI (2003), pp. 108-111), por otros como auténticas penas (Zugaldía Espinar, José Miguel (1997). "Delitos contra el medio ambiente y responsabilidad criminal de las personas jurídicas". En Bacigalupo Zapater, Enrique (director): Empresa y delito en el nuevo $C P$, Madrid: Consejo General del Poder Judicial, pp. 211-239; ZúñIGa Rodríguez, Laura (2009) Bases para un modelo de imputación de responsabilidad penal a las personas jurídicas. $3^{a}$ ed. Navarra: Thomson-Aranzadi, Cizur Menor, pp. 208-209) o como un tertium genus de sanciones penales (De la Fuente Honrubia, Fernando (2004) Las consecuencias accesorias del artículo 129 del Código Penal. Valladolid: Lex Nova, pp. 79-80). Por destacar tan solo los encuadramientos sistemáticos más recurrentes entre aquellos autores que se han ocupado de intentar descubrir su naturaleza jurídica.

7 De esta opinión es, entre otros, Zugaldía Espinar (1997) 327, quien considera que estamos ante auténticas penas.

8 Para De la Fuente Honrubia (2004) 79-80, así como para la jurisprudencia, se trataría de consecuencias accesorias a la pena impuesta a una persona física, de tal forma que no se podrían acordar en sentencia definitiva sin una persona física condenada a una pena principal. 
penas para las personas jurídicas ${ }^{9}$, aunque lo cierto es que el contenido material de las mismas no resulta, en términos generales, novedoso, toda vez que se trata de un catálogo de sanciones prácticamente idéntico al de las preexistentes consecuencias accesorias, lo cual ha llevado a algún autor a hablar de fraude de etiquetas ${ }^{10}$. En realidad, del nuevo listado de penas -contenido en el art. 33.7 CP-, solo la multa y la inhabilitación para obtener subvenciones y ayudas públicas, para contratar con el sector público y para gozar de beneficios e incentivos fiscales o de la Seguridad Social son nuevas en relación con el catálogo de consecuencias accesorias previo. A pesar de ello, el abandono de la timorata fórmula de las consecuencias accesorias y el establecimiento de un auténtico sistema de responsabilidad penal para las personas jurídicas ha supuesto una revolución sustantiva y procesal. Solo con la introducción de esta reforma se puede afirmar, sin titubeos, que las personas jurídicas son sujetos activos del delito, y por ende, sujetos pasivos del proceso penal.

Algo muy similar ha ocurrido en Chile donde, si bien con anterioridad, el ordenamiento había previsto esporádicamente sanciones en las que, en cuanto impuestas por tribunales penales y con efecto directo sobre las personas jurídicas, podían verse como genuinas penas contra las mismas ${ }^{11}$, es la primera vez que esto se hace de un modo tan abierto y explícito, de la mano, además, del establecimiento de un verdadero sistema de responsabilidad penal propio de tales entidades, con explicitación de los presupuestos específicos de la misma y de las circunstancias que la modifican, con penas y reglas de determinación también específicas y con las adaptaciones procesales básicas para su aplicación práctica ${ }^{12}$. En Chile, la regulación de la responsabilidad penal de las personas jurídicas también se encuentra, al igual que ocurre en Italia ${ }^{13}$, en una ley especial que integra los aspectos procesales y sustantivos. Se trata de la Ley no 20.393, ya

9 Para algunos autores, entre los que destaca Zugaldía Espinar (1997) 208-209 las consecuencias accesorias ya constituían auténticas penas a pesar del nomen iuris empleado por el legislador.

10 Entre otros, Zúñiga Rodríguez (2009) 256; Gómez Tomillo, Manuel (2010) Introducción a la responsabilidad penal de las personas juridicas en el sistema español. Valladolid: Lex Nova, pp. 38-39.

11 Especialmente expresivo era el art. 173 de la Ley núm. 13.305, de 6 de abril de 1959, cuyo inciso tercero preveía la "pena accesoria" de disolución (cancelación, revocación de autorización de existencia o disolución anticipada) de la persona jurídica en caso de reincidencia en conductas monopólicas.

12 Hernández Basualto (2010) 208, quien considera un acierto que se hayan desechado soluciones más ambiguas acarrean serios problemas interpretativos.

13 En este país la regulación está contenida en el Decreto Legislativo 8 giugno 2001, n. 231, "Disciplina della responsabilita' amministrativa delle persone giuridiche, delle societa' e delle associazioni anche prive di personalita' giuridica, a norma dell'articolo 11 della legge 29 settembre 2000 , n. 300". 
citada, que establece la responsabilidad penal de las personas jurídicas en los delitos de lavado de activos, financiamiento del terrorismo y cohecho.

El objeto de este artículo será estudiar las diferencias básicas que existen entre la regulación procesal chilena y espańola en lo atinente al nuevo régimen de responsabilidad penal de las personas jurídicas. El análisis se centrará en tres cuestiones básicas: en primer lugar, se estudiará el estatus de la persona jurídica imputada en el proceso, para lo cual habrá que determinar en qué condición interviene el ente en el proceso, detallando qué derechos procesales se le reconocen, así como en qué medida se desarrolla tal reconocimiento y con qué límites. En segundo lugar, se intentará determinar el momento adecuado para formalizar la investigación penal frente a la persona jurídica a través de su imputación, momento procesal clave que implica, por un lado, la adquisición de un nuevo estatus por parte del ente, que queda sujeto al proceso y, por otro lado, supone el nacimiento de su derecho de defensa, siendo preciso oírle, en este temprano estadio del enjuiciamiento, para darle la oportunidad de alegar lo que crea conveniente en su descargo. En tercer y último lugar, se realizará una aproximación al tema de la representación de la persona jurídica en el proceso penal, así como al posible conflicto de intereses que puede surgir entre la entidad y su representante en el proceso, cuando este último se encuentra también personalmente imputado. Para ello se examinará cómo y a quién se designa para representar a la entidad en las actuaciones procesales, y qué estatus tiene ese representante, encargado de ejercer el derecho de defensa en su nombre, en los distintos ordenamientos jurídicos.

\section{1) El ESTATUS DE LA PERSONA JURÍdicA COMO PARTE PASIVA DEL PROCESO PENAL}

\section{1) ¿EN QUÉ CONDICIÓN INTERVIENE LA PERSONA JURÍDICA EN EL PROCESO?}

El primer aspecto a tratar es el del estatus de la persona jurídica como parte pasiva del proceso penal, esto es, en qué condición interviene la entidad en el proceso, lo que determinará, a su vez, qué tratamiento se le ha de dispensar. Como se verá, en la misma línea que el ordenamiento italiano $^{14}$, la regulación chilena establece expresamente que a la persona jurídica le serán aplicables las disposiciones relativas al imputado en tanto

\footnotetext{
14 En este sentido el art. 35 del Decreto Legislativo italiano de 8 de junio de 2001, n. 231 ya citado, dispone que al ente le serán aplicables las disposiciones procesales relativas al imputado, en cuanto compatibles.
} 
sean compatibles con su naturaleza -art. 21 Ley no 20.393-, cláusula general que no existe en el ordenamiento espańol.

Cuando una persona jurídica, u otro ente colectivo, ocupan la posición pasiva en un proceso penal surge la duda de qué tratamiento o consideración merece tal sujeto en el marco del enjuiciamiento. Resolver esta cuestión resulta básico para determinar, de forma coherente, qué posición ocupa el ente en el proceso, y por ende qué derechos y garantías le asisten y en qué medida y con qué límites puede ejercitarlos, así como qué intervenciones se pueden acordar en relación con sus bienes y derechos. En definitiva, para establecer cuál es el estatus procesal penal de una persona jurídica objeto de enjuiciamiento es necesario, en primer lugar, determinar en qué consideración interviene la misma en el proceso. Las posibilidades que se plantean para resolver tal cuestión son principalmente dos: asimilar a la persona jurídica con el responsable civil o bien considerarla como un auténtico imputado. En este sentido, resulta interesante la propuesta de Del Moral García, consistente en considerar a la persona jurídica responsable penal como una figura a caballo entre el imputado y el tercero responsable civil. El autor reconoce que, aunque por vía de principio la persona jurídica debe ser traída al proceso penal en una cualidad más asimilable a la de imputado que a la de tercero responsable civil, en todo aquello del status de imputado que exija o presuponga la individualidad física habrá de abandonarse el paralelismo y encontrar los referentes para la analogía en los terceros responsables civiles, posición que siempre ha podido ser ocupada por persona jurídicas ${ }^{15}$.

Sin contradecir la última afirmación del citado autor, tratar a la persona jurídica, sobre la que recae una sospecha criminal, como una figura a caballo entre el imputado y el tercero responsable civil, responde a una consideración, a mi juicio errónea, que parte de que el tratamiento y el estatus que la legislación otorga al imputado responde a su consideración como persona física o natural, con dignidad humana, y no a su condición de persona sujeta a un proceso penal, y pasible de pena, como consecuencia del ejercicio del ius puniendi estatal. Pero, a mi modo de ver, la condición de imputado se fundamenta precisamente en la sujeción que supone para el sujeto pasivo el proceso penal, en el marco del cual se le deben reconocer una serie de derechos y posibilidades de actuación, en orden a descargarse de las responsabilidades que presuntamente se le imputan y que, eventualmente, puede terminar con una condena que

15 Del Moral García, Antonio. "Peculiaridades del juicio oral con personas jurídicas acusadas”. En Serrano Butragueño, Ignacio; Del Moral García, Antonio (coordinadores). El juicio oral en el proceso penal. Granada: Comares, pp. 721-762, p. 725. 
implique una interdicción de derechos enormemente aflictiva para la libertad societaria ${ }^{16}$.

La propuesta del citado autor, consistente en destilar de las normas aplicables a la persona física imputada lo que es esencial o nuclear, es decir, lo que es el principio, y prescindir de las consecuencias del principio que solo tienen sentido en relación con las personas físicas ${ }^{17}$, es algo exigido por la propia naturaleza de la persona jurídica, que hace que ciertos derechos pierdan su sentido dada la diferencia ontológica entre las personas físicas y las jurídicas. Pero, para tomar en consideración tal afirmación, hubiera sido más claro y técnicamente más correcto, establecer un artículo similar al art. 35 del Decreto Legislativo italiano n. 231, según el cual al ente le serán aplicables las disposiciones procesales relativas al imputado, en cuanto compatibles, o al art. 21 de la Ley chilena 20.393, que establece que "en lo no regulado en esta ley, serán aplicables a las personas jurídicas las disposiciones relativas al imputado, al acusado y al condenado, establecidas en el Código Procesal Penal y en las leyes especiales respectivas, siempre que aquéllas resulten compatibles con la naturaleza especifica de las personas jurídicas". En la regulación procesal española no existe precepto equivalente a los citados, que equipare, en términos generales, a la persona jurídica investigada con el imputado. Sin embargo, tal asimilación se puede derivar del fundamento del estatus de imputado que, como ya se ha expresado, se entiende que radica en la sujeción que el proceso supone para quien va a ser enjuiciado en su seno. En definitiva, si la persona jurídica está sujeta a un proceso penal, ocupando la posición de parte pasiva en el mismo, en el cual se le puede terminar imponiendo una pena, ha de ser considerada y tratada como un imputado, sin que su distinta naturaleza ontológica resulte determinante a tales efectos.

En este sentido, se podría afirmar que el derrumbamiento del principio societas delinquere non potest ha dejado obsoletas las definiciones de imputado como persona física viva a la que se atribuye un hecho puni$\mathrm{ble}^{18}$, ya que, la posibilidad de exigir responsabilidad penal a las personas jurídicas las convierte de forma automática en sujetos pasivos del proceso penal sin necesidad de un pronunciamiento legislativo al respecto ${ }^{19}$. Por

16 Piénsese, por ejemplo, en la pena de disolución, que implica la muerte civil de la entidad, y por ende su desaparición jurídica y económica.

17 Del Moral (2010) 726.

18 En este sentido, Nieva Fenoll, Jordi (2012) Fundamentos de Derecho procesal penal. Buenos Aires: Bdf, p. 81, dice que desde hace algún tiempo se está debatiendo si puede ser imputada la persona jurídica. Por tanto, puede ser puesto en cuestión el postulado inicial de que acusado debe ser una persona física capaz.

19 En este sentido, Gascón Ichausti, Fernando (2010) "Consecuencias procesales del nuevo régimen de responsabilidad penal de las personas jurídicas: la persona jurídica como sujeto pasivo del proceso penal”. En Gascón Inchausti, Fernando (coordinador). Repercusiones sobre el Proceso penal de la LO 5/2010, de reforma del Código Penal. Navarra: Aranzadi, Thom- 
esta razón, la modificación de la regulación material implica también, implícitamente, un cambio en el concepto de imputado. Siguiendo a DEL Olmo Del $\mathrm{Olmo}^{20}$, y teniendo en cuenta la reforma penal operada en relación con la responsabilidad de las personas jurídicas, podemos definir al imputado como aquella persona física o jurídica determinada a quien se atribuya más o menos fundadamente la comisión de un hecho punible. Esta conclusión es automática e irremediable, pues si el imputado es, en términos generales, toda persona a la que se imputa un acto punible ${ }^{21}$, y el art. 31 bis CP, así como el art. 3 de la ley chilena, imputan responsabilidad penal a las personas jurídicas, implícitamente están reconociendo la condición de imputado a la entidad.

Al no existir en el ordenamiento español, un reconocimiento expreso de tal condición, se hace necesario argumentar en que se fundamenta tal afirmación. Basta con percatarse de que el CP, en los arts. 33.7 y 66 bis, establece auténticas penas y criterios para su imposición a las personas jurídicas, mientras que el art. 1 LECrim"2 dice que "no se impondrá pena alguna por consecuencia de actos punibles -...) sino de conformidad con las disposiciones del presente Código o de Leyes especiales y en virtud de sentencia dictada por Juez competente". Por tanto, desde el momento en que las personas jurídicas pueden ser acreedoras de penas, en virtud de la regulación penal sustantiva, se convierten ineludiblemente en destinatarias de las disposiciones de la LECrim, por lo que, antes de ser acusadas, han de ser imputadas, y en tal condición han de poder ejercitar el derecho de defensa. La conclusión de la precedente argumentación ha sido positivamente acogida por el nuevo art. 119 de la LECrim, que preceptúa que "cuando de acuerdo con lo dispuesto en el art. 118 de esta ley, haya de procederse a la imputación de una persona jurídica, se practicará con ésta la comparecencia prevista en el art. 775 (...)". En definitiva, "cualquier actuación procesal de la que resulte la imputación de un delito" dirigido contra una persona jurídica, implicará la asunción por la misma de la condición de imputada ${ }^{23}, y$

son Reuters, pp. 19-104, pp. 29-30, afirma que en los modelos de responsabilidad penal en sentido estricto de la persona jurídica esta es directamente y sin más imputada, acusada o condenada, sin necesidad de que se diga expresamente.

20 Del Olmo Del Olmo, Juan A. (1999) Garantias y tratamiento del imputado en el proceso penal. Madrid: Trivium, p. 23.

21 López Barja de Quiroga, Jacobo (2004) Tratado de Derecho Procesal Penal, Navarra: Aranzadi, p. 797.

22 Ley de Enjuiciamiento Criminal aprobada por el Real Decreto de 14 de septiembre de 1882 .

23 Un estudio reciente sobre las distintas formas de adquisición de la condición de imputado se puede ver en López Yagües, Verónica (2011) "La condición de imputado en el proceso penal español. Formas de adquisición y status jurídico que conlleva. Ideas para su reforma”. En Asencio Mellado, José Ma.; Fuentes Soriano, Olga (directores); Cuadrado Salinas, Carmen (coordinadora). La reforma del proceso penal. Madrid: La Ley, pp. 20-111, pp. 29-60. 
por ende, el reconocimiento del correspondiente estatus, es decir, del haz de derechos y garantías que se otorgan al imputado en cuanto tal.

\section{2) ¿QUÉ DERECHOS SE LE ATRIBUYEN A LA PERSONA JURÍdiCA IMPUTADA?}

En relación con el contenido material del estatuto reconocido a la persona jurídica imputada, el segundo párrafo del art. 21 de la Ley chilena, señala, sin ánimo de exhaustividad, una serie de preceptos del Código Procesal Penal chileno -en adelante CPP- que contienen ciertos derechos y garantías que, según la literalidad del precepto, podrán ser ejercidos por cualquier representante de la entidad. Tales derechos son la presunción de inocencia -art. 4 CPP-, la adquisición de la calidad de imputado, con sus facultades, derechos y garantías, desde que se dirija el procedimiento contra ella -art. 7 CPP-, el derecho a defensa letrada y a intervenir personalmente en las actuaciones judiciales -art. $8 \mathrm{CPP}-$, la cautela prestada por el juez de garantías que tomará las medidas adecuadas para que el ejercicio de los derechos sea efectivo, pudiendo incluso llegar a suspender el procedimiento -art. $10 \mathrm{CPP}-$, el derecho de información de los hechos que se le imputan y de los derechos que le asisten -art. $93 \mathrm{CPP}-$, el derecho de asistencia letrada desde el inicio de la investigación -art. 93 $\mathrm{CPP}-$, el derecho de solicitar diligencias de investigación al Ministerio Público y de asistir a las que se celebren -arts. 93 y 183-, el derecho a solicitar audiencia al Juez -art. $93 \mathrm{CPP}-$, el derecho a solicitar que se active o se formalice la investigación y a conocer su contenido siempre que no haya sido declarada secreta -arts. 93 y 186 CPP-, el derecho a solicitar el sobreseimiento y a recurrir la resolución denegatoria del mismo -art. 93 CPP-, el derecho a guardar silencio o a declarar sin estar bajo juramento -art. $93 \mathrm{CPP}-$, el derecho a no sufrir tratos inhumanos o degradantes y a no ser juzgada en ausencia -art. $93 \mathrm{CPP}-$, el derecho a usar su declaración como medio de defensa -art. $98 \mathrm{CPP}-$, el derecho a designar libremente un defensor, a que sea designado uno de oficio o a defenderse por sí misma -art. $102 \mathrm{CPP}-$, el derecho a solicitar una comparecencia ante el Ministerio Público -art. 193 CPP-, el derecho a declarar voluntariamente ante el Ministerio Público tras ser informado de los hechos que se le imputan y de sus derechos -art. 194 CPP-y el derecho a reiterar la solicitud de diligencias de investigación no practicadas por causas ajenas a la voluntad de las partes -art. 257 CPP-. Estos derechos y garantías se reconocen, por remisión al CPP, a la persona jurídica imputada, acusada o condenada, pero serán ejercitados, en su nombre, por cualquier representante de la misma.

En cuanto a la regulación española el estatuto procesal de la persona jurídica, está recogido en la propia LECrim, y no en una ley especial. En 
los preceptos introducidos por la $\mathrm{LMAP}^{24}$ se van recogiendo, de forma dispersa, algunos de los derechos y garantías que le corresponden a la entidad enjuiciada en un proceso penal. En primer lugar el art. 119 LECrim, recoge la forma de adquisición de la condición de imputado, remitiéndose a lo establecido para las personas físicas, de la cual se deriva la posibilidad de ejercitar el derecho de defensa -art. 118 LECrim-. El art. 119 , al regular esa primera comparecencia en la que la entidad adquiere la condición de imputada le reconoce algunos otros derechos, como el de designar abogado y procurador de confianza o que, en su defecto, sea designado uno de oficio y el derecho a recibir información sobre los hechos que se le imputan. Otros derechos que se le reconocen expresamente son el derecho a asistir a las diligencias de investigación o de prueba anticipada -art. 120.1 LECrim-, el derecho a declarar sobre los hechos y la participación en los mismos de la entidad y de las demás personas que hayan intervenido en los mismos, pudiendo optar por guardar silencio, no declarar contra sí misma y no confesarse culpable -art. 409 bis $\mathrm{CP}-$, el derecho a la inviolabilidad del domicilio -que se le reconoce implícitamente por el art. 554.4 LECrim al ofrecer una definición específica de lo que constituye el ámbito domiciliar inviolable de una persona jurídica-, y por último, en el marco del juicio oral, se le reconoce el derecho a estar representada por una persona que especialmente designe para un mejor ejercicio de su derecho de defensa, otorgando a tal representante los derechos a guardar silencio, a no declarar contra sí mismo y a no confesarse culpable, así como a ejercer el derecho a la última palabra -art. 786 bis LECrim-.

En este momento, ya es posible alcanzar una primera conclusión de la comparación realizada: la regulación chilena resulta más garantista que la española. En primer lugar, por la ausencia en la regulación española de una cláusula genérica que equipare al imputado persona física con la persona jurídica imputada. Aunque como ya se ha argumentado, tal equiparación se puede deducir a través de una interpretación garantista de la legislación positiva. En segundo lugar, porque los derechos, que la regulación positiva atribuye expresamente a la entidad enjuiciada, se reconocen de forma más exhaustiva y más amplia en la regulación chilena. Para justificar tal afirmación a continuación se realizará un análisis comparativo de aquellos derechos procesales que la regulación chilena reconoce expresamente y que el ordenamiento español omite, o solo reconoce de forma implícita.

En primer lugar, en la regulación española se echa en falta un reconocimiento expreso del derecho a la presunción de inocencia. Aunque

24 Ley 37/2011, de 10 de octubre, de medidas de agilización procesal, que modifica la LECrim introduciendo, en palabras de su propia Exposición de Motivos, ciertas modificaciones inexcusables, exigidas por la nueva situación derivada de la reforma operada en el Código Penal por la Ley Orgánica 5/2010, de 22 de junio, y relativas a las implicaciones procesales del régimen de responsabilidad penal de las personas jurídicas. 
tal derecho no se reconoce explícitamente, cabe deducirlo del art. 24.2 Constitución Española que se refiere al mismo en términos muy amplios, indicando que "todos (...) tienen derecho a la presunción de inocencia", luego donde la ley no distingue no se debe hacer distinción, y mucho menos si es con el fin de restringir derechos fundamentales.

En segundo lugar, se echa en falta un precepto similar al art. 10 $\mathrm{CPP}$, que permite al juez de garantías, que estime que el imputado no está en condiciones de ejercer los derechos que le otorgan las garantías judiciales, legales y constitucionales vigentes, adoptar, de oficio o a petición de parte, las medidas necesarias para permitir dicho ejercicio. Este precepto puede resultar especialmente útil para resolver el conflicto de intereses que puede existir entre el representante de la persona jurídica en el proceso y la entidad, se trataría de una facultad que el juez de garantías en Chile o el juez de instrucción en España podrían usar para exigir el nombramiento de un nuevo representante de la entidad, que asumiese el ejercicio de las facultades autodefensivas de la misma, cuando el representante citado o designado se encontrase coimputado en la causa. Es posible que, a falta de un precepto en tal sentido, se pudiese entender que el juez de instrucción español podría, en el ejercicio de sus genéricas facultades de garantía de los derechos del imputado, intervenir de oficio en aras a garantizar el correcto ejercicio del derecho de defensa por la persona jurídica, pero un reconocimiento expreso aclararía, sin duda, la cuestión. Sobre todo, si se tiene en cuenta que el juez instructor, como director de la investigación que es en el ordenamiento procesal español, posterga su papel de juez de garantías a un segundo plano.

En tercer lugar, resulta inexplicable el olvido del art. 120 LECrim, cuando hace referencia a que el representante especialmente designado por la entidad, o en su caso el abogado, serán informados de los hechos que se imputan a la persona jurídica por escrito o mediante traslado de la denuncia o querella, sin hacer referencia alguna a la información sobre los derechos que le asisten. En mi opinión, esto se debe a un lapsus del legislador que mantuvo, en este punto, lo dispuesto por el Proyecto de LMAP $^{25}$ del año 2011, en el que se establecía que la primera comparecencia, en la que se produce la imputación, se celebraría sin tomar declaración alguna a quienes compareciesen en nombre de la entidad. Esto, constituía una lógica consecuencia de la consideración de las disposiciones relativas a la declaración del imputado y del acusado eran incompatibles con la naturaleza de la persona jurídica -art. 120.3 Proyecto-, y del entendimiento de la presencia del representante de la entidad en la primera comparecencia, y aún durante el resto de las actuaciones

25 Proyecto de Ley de medidas de agilización procesal publicado en el Boletín oficial de las Cortes Generales el 18 de marzo del año 2011. 
procesales, como meramente testimonial, considerando su inasistencia, en todo caso, irrelevante. En este sentido, el art. 119.1. b) del Proyecto establecía lo siguiente: "la comparecencia se practicará exclusivamente con el abogado de la entidad. No obstante, la persona juridica imputada podrá designar expresamente a un representante para que asista a dicho acto junto al letrado. La inasistencia del representante especialmente designado para acudir al acto de primera comparecencia no impedirá la práctica del mismo con el abogado de la entidad". Por fortuna, esta regulación tan poco garantista, y por ello dudosamente constitucional, ha sido modificada durante la tramitación parlamentaria de tal forma que, con la regulación vigente en la LECrim, la primera comparecencia se practica con el representante especialmente designado por la persona jurídica, sin perjuicio de que su inasistencia provoque la celebración del acto con el abogado de la entidad -art. 119.1.b LECrim-, además, cuando se haya procedido a la imputación de la persona jurídica, se tomará declaración al representante especialmente designado por ella -art. 120.1 LECrim-. Resulta evidente que, antes de tomar declaración al representante, habrá que informarle, no solo de los hechos que se le imputan a la persona jurídica, sino también de los derechos que le asisten en la prestación de la declaración. La laguna señalada puede ser integrada por lo dispuesto en el art. 409 bis LECrim que establece que a la declaración del representante le serán aplicables los preceptos dispuestos en el capitulo relativo a las declaraciones de los procesados en lo que no sea incompatible con la especial naturaleza de la persona jurídica, remisión que supone, entre otras cosas, que el representante de la entidad ha de ser informado de sus derechos antes de declarar y que el mismo puede prestar declaración ante el Juez cuantas veces quisiere -art. 400 LECrim-.

Otros derechos de extraordinaria relevancia que la LECrim tampoco reconoce expresamente, ni siquiera en relación con las personas físicas, son el derecho del investigado a solicitar que se formalice la investigación en su contra y se le informe del contenido de la misma, así como el derecho a usar la declaración como medio de defensa. En cuanto al primero de los derechos señalados, esto es, el de solicitar la formalización de la investigación o la propia imputación, en aras a poder desarrollar el derecho de defensa, la dicción de la LECrim -art. 118- se queda corta ya que posterga el nacimiento del derecho de defensa a la existencia de una comunicación formal que suponga la atribución de un hecho punible a la entidad. Cabe preguntarse, por tanto, qué ocurre si el presunto imputado se entera de la existencia del procedimiento penal antes de que se le comunique formalmente, resultando evidente que debe tener el derecho de defenderse, incluso preventivamente. Por lo demás, en su devenir el estatus de la parte acusada puede pasar por diversos estadios. Es obvio que en cualquiera de ellos, y no solo en los que menciona cicateramente la 
LECrim, debe darse al imputado la adecuada ocasión de defenderse ${ }^{26}$. En este punto, la regulación chilena resulta, nuevamente, más garantista que la española, ya que permite al imputado provocar la formalización de la investigación y el consiguiente nacimiento de su derecho de defensa -arts. 93 y 186 CPP-, impidiendo, de esta forma, que se retrase la imputación, para avanzar en la investigación de espaldas al sujeto indagado.

Por último, el reconocimiento expreso de la declaración del imputado como medio de defensa -art. $98 \mathrm{CPP}-$, no encuentra parangón en la regulación española. De hecho, cuando el art. 409 bis LECrim se refiere al objeto sobre el que versará la declaración de la persona jurídica imputada, señala que la misma irá dirigida a la averiguación de los hechos, así como a la participación en ellos de la entidad imputada y de las demás personas que hubieran también podido intervenir en su realización ${ }^{27}$. Esto denota un cierto resabio inquisitivo de la legislación española, que sigue viendo la declaración del imputado, como medio de investigación en manos de la acusación, más que como un instrumento de defensa. La misma idea subyacía, a mi modo de ver, en el Proyecto de LMAP, que prescindía de la declaración del representante de la entidad ${ }^{28}$. Algunas voces justificaban y compartían esta posibilidad argumentando que no es ineludible la declaración de quien comparece como representante legal de la persona jurídica. En este sentido, se diferenciaba conceptualmente el acto de imputación, orientado a satisfacer el derecho de ser informado de la acusación, y la declaración del imputado, como un acto de investigación, concluyendo que esta última no sería necesaria con las personas jurídicas ya que, probablemente, el representante no tendría un conocimiento directo de los hechos, con lo que su declaración como acto de investigación carecería de sentido por su previsible ineficacia para los efectos de la averiguación de los hechos ${ }^{29}$. En mi opinión, ni la argumentación precedente ni la solución del Proyecto de LMAP, resultan asumibles, toda vez que se

Ramos Méndez, Francisco (2011) Enjuiciamiento criminal. Décima lectura constitucional, Barcelona: Atelier, p. 34.

27 En el mismo sentido, para el interrogatorio de la persona física imputada, el artículo 389 bis LECrim establece que "Las preguntas que se le hagan en todas las declaraciones que hubiera de prestar se dirigirán a la averiguación de los hechos y a la participación en ellos del procesado y de las demás personas que hubieren contribuido a ejecutarlos o encubrirlos", y el artículo 385 senala que "El Juez, de oficio o a instancia del Ministerio Fiscal o del querellante particular, hará que los procesados presten cuantas declaraciones considere convenientes para la averiguación de los hechos".

28 En este sentido, el art. 120.3 que el Proyecto de LMAP pretendía introducir en la LECrim establecía lo siguiente: "No serán aplicables a las personas jurídicas imputadas las disposiciones que sean incompatibles con su especial naturaleza. En particular, no les serán aplicables las siguientes disposiciones: a) Las relativas a la declaración de imputado, que no procederá en ningún caso sin perjuicio de las alegaciones por escrito que se puedan presentar por el abogado defensor o de cuantas declaraciones de testigos o de personas físicas imputadas sean propuestas por el mismo". Del Moral (2010) 730-731. 
olvidan de la otra cara o faceta de esa declaración, cual es la de constituir un medio de defensa ${ }^{30}$. El propio Tribunal Constitucional español ${ }^{31}$ se refiere a esta primera comparecencia como "una garantía básica que debe concurrir en todo proceso penal", cuya función esencial es la asunción formal del estatus de imputado y su interrogatorio judicial, antes de haberse formulado acusación en su contra. En la misma resolución, el Alto Tribunal continúa diciendo que "los principios de contradicción e igualdad están incluidos entre las garantías del art. 24 de la Constitución Española por ser consustanciales al proceso. Y que, del principio de igualdad de armas, lógico corolario de la contradicción, se deriva la necesidad de que las partes cuenten con los mismos medios de ataque y defensa, idénticas posibilidades de alegación, prueba e impugnación, sin que sean admisibles modulaciones o excepciones que puedan establecerse en la fase de instrucción por razón de la naturaleza de la actividad investigadora". Por tanto, el Tribunal Constitucional ha establecido, reiteradamente, en su jurisprudencia que en la primera comparecencia el juez ha de tomar declaración al imputado con el objeto, no solo de indagar su participación en los hechos, sino también de que pueda exculparse de los cargos contra él existentes ${ }^{32}$. En definitiva, privar a la persona jurídica imputada de la posibilidad de ser oída en esa primera comparecencia, como hacía el Proyecto de LMAP, implicaría un menoscabo de sus posibilidades defensivas y un retraso en el nacimiento del derecho de defensa sin una justificación objetiva y razonable para ello. Lo verdaderamente importante, a mi modo de ver, es que la persona jurídica tenga ya desde este momento inicial la posibilidad de esgrimir argumentos defensivos contra la sospecha criminal que recae sobre ella.

30 En este sentido Revilla GonzÁlez, José Alberto (2000) El interrogatorio del imputado, Valencia: Tirant lo Blanch, pp. 83-84, que sitúa el interrogatorio entre las manifestaciones de la autodefensa aun cuando reconoce que también se trata de un medio probatorio. También señala Buzzeli, Silvia (1972) "Sull' interrotario dell' imputato", RDP, pp. 464 y 480-483, que el principio nemo tenetur se deteger conduce a considerar el interrogatorio como medio de defensa y no de prueba. En el mismo sentido Gimeno Sendra, Vicente (2010) Manual de Derecho Procesal Penal. $2^{a}$ ed. Madrid: Colex, pp. 221-222, señala que la finalidad del acto de imputación judicial es posibilitar el interrogatorio judicial del imputado que por una parte constituye un acto de investigación sujeto a las disposiciones sobre las indagatorias (385-497 LECrim) y por otro lado constituye un acto defensa porque es la primera posibilidad que tiene el imputado de, asistido de su abogado, exculparse de los hechos y poder convencer al juez de su ausencia de responsabilidad penal, obteniendo en tal caso un sobreseimiento; López YaGües (2011) 106, llama la atención sobre el carácter mixto del interrogatorio en tanto que cumple, prioritariamente una función defensiva, pero sirve al tiempo a otros fines del proceso claramente averiguatorios y, en ciertas circunstancias, también probatorios.

31 Tribunal Constitucional (Pleno) sentencia núm. 186/1990 de 15 de noviembre, RTC 1990/186, FJ 4º. Véase también Tribunal Constitucional (Sala Primera) sentencia núm. 44/1985 de 22 marzo, RTC 1985\44, FJ 3º.

32 En el mismo sentido, López Yagües (2011) p. 43, afirma que la toma de declaración en el acto de imputación constituye quizás la primera, pero sin duda la más clara oportunidad de defenderse. 
Vedarle cualquier posibilidad de ser oída en esta primera comparecencia sería contrario a los principios de igualdad y contradicción que informan y legitiman el proceso penal. En este orden de ideas, cabe recordar que si hay una imputación formal es porque existe una sospecha que puede fundarse en una denuncia, una querella o una actuación policial, judicial o del ministerio público ${ }^{33}$. Esta imputación, a la que el Ministerio Público chileno o el juez de instrucción español han cubierto con un manto de verosimilitud ${ }^{34}$, al acogerla como posible a través de la formalización de la investigación o del acto de imputación respectivamente, debe ir seguida de una posibilidad real para la persona jurídica imputada de neutralizar esa sospecha o, más bien, su verosimilitud. En todo caso, hay que tener presente que la consideración de las personas jurídicas como un mero objeto del proceso penal y no como un verdadero sujeto, con derechos y capacidad de actuación para ejercitarlos, puede llevar incluso a vaciar de contenido el régimen de responsabilidad penal de las personas jurídicas.

\section{3) EN PARTicular, la PRoblemática del derecho a No DECLARAR}

Especialmente controvertido resulta el tema del alcance del derecho a no declarar reconocido a la persona jurídica tanto por la regulación española -arts. 409 bis y 786 bis 1 LECrim-, como en la regulación chilena -art. 21 Ley 20.393-. Esta última reconoce a la persona jurídica, en tanto que se encuentre imputada o acusada en un proceso, el derecho a no declarar contra sí misma, que podrá ser ejercido por cualquier representante de la persona jurídica. Por su parte, la regulación española reconoce tal derecho en dos preceptos diferentes en atención a dos momentos procesales distintos. En primer lugar, se le reconoce tal derecho en la declaración inicial tomada al representante en la primera comparecencia, entendiéndose además que su inasistencia a dicho acto supone que la persona jurídica se acoge ope legis a su derecho a no declarar -art. 409 bis LECrim-. En segundo lugar, en el marco del juicio oral, también se reconoce el derecho a no declarar del representante especialmente designado por la persona jurídica para ocupar el banquillo de los acusados -art. 786 bis LECrim-.

Admitiendo por tanto, sin ambages, que a la persona jurídica imputada le corresponde el derecho a no declarar contra sí misma y a no confesarse culpable habrá que determinar a través de qué personas se ejercerá tal derecho, como instrumento de aquel otro más genérico de de-

\footnotetext{
33 López YaGües (2011) 26-60, establece las distintas formas de adquisición de la condición de imputado.

34 Serra Domínguez, Manuel (1969) Estudios de Derecho Procesal. Barcelona: Ariel, p. 675, afirma que para devenir imputado no es suficiente ser sospechoso, sino que precisa que la sospecha provenga de una persona dotada de poder jurisdiccional.
} 
fensa. Llegados a este punto resulta necesario analizar dos sentencias del Tribunal Constitucional español ${ }^{35}$, especialmente relevantes a los efectos del presente análisis. En ambas resoluciones, los recurrentes en amparo entienden vulnerado su derecho a no autoincriminarse, alegando que se ha seguido contra ellos un proceso penal, en el cual han resultado condenados, con base en pruebas obtenidas por la Administración en el marco de sendos procesos de liquidación de tributos, en los que se han producido requerimientos coactivos de información, es decir, bajo amenaza de sanción. Lo realmente significativo es la argumentación usada por el Tribunal Constitucional para concluir que no existe vulneración del derecho a no autoincriminarse, ya que en las dos resoluciones mantiene que los requerimientos de información y las eventuales sanciones por su incumplimiento se dirigieron, en todo momento, a las entidades mercantiles de las cuales los recurrentes eran, respectivamente, administradores. Luego, la coacción legal, consistente en la amenaza o la efectiva imposición de sanciones por no colaborar con la Inspección de los tributos aportando pruebas y documentos los recurrentes posteriormente condenados en el proceso penal. En definitiva, el Tribunal Constitucional español entendió en ambas resoluciones que, a estos efectos, una persona jurídica y su representante legal son sujetos distintos y autónomos, por lo que la coacción ejercida sobre uno de ellos no contamina ni invalida las pruebas, que pueden servir para condenar al otro. Esta argumentación, que ha sido criticada por la doctrina por ser excesivamente formalista ${ }^{36}$, desconoce que, si se niega el derecho a no declarar contra la persona jurídica a sus representantes legales, por entender que son sujetos diferentes, se estaría vaciando de contenido el derecho a la no autoincriminación de la persona jurídica ${ }^{37}$, toda vez que la misma declarará o guardará silencio a través de personas físicas, por ser ontológicamente imposible que lo haga por sí misma.

Tanto la regulación espańola como la chilena dejan claro que la imputada en el proceso penal, es la propia entidad y no sus representantes legales. Pero, lo cierto es que el interrogatorio de la persona jurídica se practicará, en todo caso, en la persona de su representante, de modo que,

35 Tribunal Constitucional (Sala Primera) Sentencias núm. 18/2005, de 1 febrero y núm. 68/2006, de 13 marzo.

36 García Berro, Florián (2010) "Derecho a no autoincriminarse de los contribuyentes y procedimiento sancionador separado: precisiones a la luz de la evolución jurisprudencial". En Quincena Fiscal Aranzadi, no 19. Navarra: Aranzadi, pp. 15-48, p. 16, habla de una actitud escapista del TC que evita pronunciarse sobre el fondo del asunto; Hernández García, Javier (2010) "Problemas alrededor del estatuto procesal de las personas jurídicas penalmente responsables", Diario La Ley, no 7427, publicado el 18 de junio. Disponible en: http://p88127.0.0.1.accedys.udc.es/accedix $0 /$ sitios/control/0incrustat.php?aplicacion $=10031$, dice que la respuesta del constitucional es un ejemplo extremo de formalismo silogístico que carece de todo empaque doctrinal para resistir en el tiempo y dar por cerrada en términos constitucionales la cuestión.

37 En tal sentido se pronuncian, entre otros, Gascón (2010) 81-82; Del Moral (2010) 742. 
si aquella quiere hacer valer su derecho al silencio, es necesario hacer portador de tal derecho a su representante durante ese interrogatorio, que bien podría plantearse como diligencia de investigación durante la instrucción o como medio de prueba durante el juicio oral ${ }^{38}$. Esta dicotomía entre el titular del derecho y quien tiene capacidad para ejercerlo ha llevado a algún autor a afirmar que, en realidad, la persona jurídica no tiene por sí misma derecho a guardar silencio ni a no confesarse culpable, sino solamente de un modo mediato, ya que ese derecho es de titularidad exclusiva de las personas físicas, a fin de que no sean presionadas -física o psicológicamente- para obtener una declaración de culpabilidad. Pues bien de ese mismo derecho gozan también los representantes de la persona jurídica, para evitar que se ejerza presión sobre ellos en cuanto a los temas que afectan a la persona jurídica. Como consecuencia ese derecho beneficia a la persona jurídica, pero no porque sea de su titularidad ${ }^{39}$. Las sentencias del Tribunal Constitucional comentadas, a mi modo de ver, vienen a negar tácitamente esta tesis, toda vez que, entienden que la presión ejercida sobre la entidad no afecta al derecho a no declarar de sus representantes, con lo que se asume implícitamente que ambas titularidades son autónomas. Más allá de las críticas que merezca la citada jurisprudencia constitucional, en mi opinión, las personas jurídicas, sí serían titulares del derecho a no declarar, en el sentido, más amplio, de no colaborar con su propia autoincriminación, dado que la carga de la prueba ha de recaer, en todo caso, sobre la parte acusadora.

Independientemente de que la persona jurídica sea titular mediata o inmediata del derecho a no declarar se hace necesario que la regulación determina con exactitud a través de qué concretas personas físicas se podrá ejercitar tal derecho, o en otras palabras, a qué sujetos, vinculados a la entidad, alcanza el este derecho en sus declaraciones. En definitiva, si hay una persona especialmente designada para defender la libertad e inocencia de la persona jurídica, esta no estará obligada a declarar en perjuicio de la misma, ya que en otro caso, su función defensiva se vaciaría de contenido. También queda fuera de toda duda que cuando los propios representantes orgánicos de la persona jurídica estén personalmente imputados en la causa tendrán derecho a guardar silencio y a no autoincriminarse. Pero, desde distintas posiciones doctrinales, y con alcances muy variados, se propone extender el derecho a no declarar a otros sujetos especialmente vinculados con la persona jurídica, distintos a su representante en juicio. Para algunos autores, la protección debiera abarcar, al menos, a todos los representantes o miembros de los órganos directivos ${ }^{40}$. En este sentido, 
Del Moral García ${ }^{41}$ concuerda con que no tendría sentido que el derecho a no declarar o a no proporcionar información sobre los hechos, pudiese ser burlado llamando como testigo a cualquiera de los miembros del órgano directivo no imputado y exigiéndole juramento. En la misma línea, Gascón Inchausti propone limitarlo a los administradores-representantes ${ }^{42}$. Esta ha sido la solución acogida por el ordenamiento suizo ${ }^{43}$ y por el chileno -art. 21 in fine Ley $20.393^{44}-$, que fijan el alcance de tal derecho, haciéndolo extensible a todos los representantes de la entidad, aunque no sean sus representantes en el proceso penal. Otros autores se inclinan por la extensión de tales derechos a todos aquellos que ocupan un puesto en el entramado organizativo de la entidad enjuiciada, aunque no sean directivos ni miembros o socios de la misma ${ }^{45}$. Esta última opción podría resultar excesivamente amplia por dificultar desproporcionadamente la persecución penal. También existen propuestas doctrinales que pasan por deslindar los hechos, estableciendo que los representantes imputados podrán guardar silencio, o incluso mentir, solo acerca de los hechos propios, pero no acerca del defecto de organización o de aquellos otros elementos fácticos que solo influirían en la condena de la persona jurídica ${ }^{46}$. Esta última hipótesis no parece factible dado que las personas físicas no pueden desdoblarse como si tuvieran dos mentes, cuando declaran como imputados o como representantes de la persona jurídica. Por tanto, la declaración se tendrá que practicar conjuntamente por todos los hechos conocidos por el representante, aunque valorando el juez, a efectos de credibilidad, el conflicto de intereses subyacente ${ }^{47}$.

En la búsqueda del necesario equilibrio entre el respeto debido a los derechos a guardar silencio y a no confesarse culpable, instrumentales del más amplio derecho de defensa, y la eficacia de la persecución penal en el descubrimiento de los delitos ${ }^{48}$, se hace necesario acotar los sujetos que han de quedar cubiertos por el manto protector que proporciona el estatus de imputado a la hora de declarar. Si partimos de la funcionalidad del

Del Moral (2010) 743.

GASCÓN (2010) 82.

Artículo $102.2^{\circ}$ Código Penal suizo.

Este precepto dispone que a las personas jurídicas les serán aplicables las disposiciones contenidas una serie de artículos del Código Procesal Penal, entre los que se encuentra el derecho a no declarar, y a renglón seguido añade que tales derechos y garantías podrán ser ejercidos por cualquier representante de la persona jurídica.

45 En este sentido se pronunció Alonso Gallo, Jesús durante el Seminario celebrado el 9 de febrero de 2010 en la Facultad de Derecho de la Universidad Complutense de Madrid sobre la responsabilidad penal de las personas jurídicas. Este autor entiende que ni los empleados y ni los directivos tendrán el deber de decir verdad en las declaraciones que presten en el procedimiento contra la persona jurídica.

46 Gascón (2010) 80.

47 Nieva (2012) 84-85.

48 Gascón (2010) 82. 
derecho objeto de análisis - a no declarar contra uno mismo y a no confesarse culpable- como una manifestación de la autodefensa del imputado, parece que no debiera hacerse extensible a quien no ostenta esa facultad autodefensiva. De lo contrario se correría el riesgo de desnaturalizar los citados derechos. Esto conduciría a limitar la aplicación de los citados de los mismos, únicamente, al representante defensivo de la persona jurídica en juicio, en tanto que a él le corresponde ejercitar en el proceso las facultades propias de la autodefensa, subrogándose, a estos solos efectos, en la posición del imputado. En cuanto al resto de los sujetos interesados en el proceso, véase los representantes o administradores ordinarios, los empleados o los socios, deberán declarar en calidad de testigos. Lo cual no obsta para que les pueda resultar de aplicación, por analogía, el art. 418 LECrim, que dispensa a los testigos de declarar acerca de una pregunta determinada cuando su contestación pueda perjudicar material o moralmente, y de una manera directa e importante, ya a la persona, ya a la fortuna de alguno de sus parientes, de entre los que aparecen determinados en el art. 416 LECrim. Si la ley dispensa a los testigos de contestar, en tales circunstancias, determinadas preguntas, con mayor motivo deberá tener lugar tal dispensa cuando la afectación se produzca para la persona o la fortuna del propio testigo ${ }^{49}$. Pero, hay que tener en cuenta las exigencias del precepto que hacen referencia a un perjuicio directo e importante, no bastando un mero riesgo eventual o indirecto ${ }^{50}$. Estas exenciones del deber de declarar a través de la regulación de los secretos -familiar y profesional- pretenden tutelar determinadas relaciones y la confianza sobre la que estas se construyen ${ }^{51}$.

Determinar en calidad de qué declaran tales personas, integrantes, en sentido amplio, de la persona jurídica, no es baladí, ya que si las mismas estuviesen sometidas al régimen jurídico de los testigos tendrían obligación de declarar y de decir la verdad y al inicio del interrogatorio se les tomaría juramento. Además, estarían obligadas a contestar a todas las preguntas que no les incumbiesen de forma directa, alzándose tal obligación solo, cuando la respuesta a una determinada pregunta, pudiese afectar de manera directa e importante a su persona o fortuna. El problema es que si un directivo o empleado declara contra la persona jurídica podría

49 Del Moral (2010) 745, entiende que resulta lógico que también sea levantada su obligación de declarar cuando el posible perjuicio económico o moral se cierne sobre él mismo, aunque sea de manera indirecta.

50 En contra, Del Moral (2010) 745 para quien sería suficiente un perjuicio indirecto.

51 Rodríguez Yagüe, Carmen (2006) "La protección de los whistleblowers por el ordenamiento español: aspectos sustantivos y procesales”. En Arroyo Zapatero, Luis; Nieto Martín, Adán (coordinadores), Fraude y corrupción en el Derecho penal económico europeo. Eurodelitos de corrupción y fraude, Cuenca: Ediciones de la Universidad de Castilla La Mancha, pp. 447484, p. 469. 
sufrir medidas disciplinarias internas ${ }^{52}$. Por ello, sería necesario otorgar cierta protección a los mismos frente a la empresa para que no tengan que ampararse en ello para no contestar, alegando una afectación importante y directa de su fortuna, consecuencia de la pérdida de su empleo. Para ello, una posibilidad podría ser establecer la nulidad del despido cuando se pruebe que la causa ha sido la declaración testifical en juicio contra los intereses de la entidad, o incluso, se podría establecer que durante un período de tiempo se presuma que esa es la causa del despido ex lege, salvo que se pruebe lo contrario.

En este orden de ideas, resulta digna de mención la figura de los whistleblowers, denunciantes cívicos o denunciantes internos, de gran importancia, ya que buena parte de los delitos económicos se descubren merced a denuncias internas de empleados o de otras personas que se sitúan dentro de la organización. Hay varios aspectos procesales interesantes en relación con la protección del denunciante, como la necesidad de regular la carga de la prueba, de tal forma que el denunciante deba demostrar solo prima facie que existe una relación entre la represalia o perjuicio que se le ha infringido y su denuncia ${ }^{53}$. De hecho, el espíritu de la legislación estadounidense de la época post Enron persigue incrementar la revelación por la propia empresa o sus empleados - whistleblowers - de los comportamiento ilícitos de que tengan noticia, impidiendo que la empresa tenga atenuaciones en la pena cuando, pese a conocer la infracción gracias a un programa de cumplimiento efectivo, no lo ha puesto en conocimiento de las autoridades. En este sentido, la filosofía de la regulación norteamericana pasa por corresponsabilizar a la propia empresa en la prevención e investigación del delito, y a cambio de su colaboración la entidad obtiene, además de rebajas en la sanción, mejor imagen y un margen de confianza para implementar autónomamente su sistema de prevención y control del delito ${ }^{54}$.

Estos mecanismos para luchar contra determinados fenómenos delictivos mediante el favorecimiento de la delación, a cambio de atenuaciones o exenciones en la pena, no están exentos de críticas. Siguiendo a RodríGUEZ YAGÜE ${ }^{55}$, se pueden señalar, entre otras, las siguientes: las referidas a la falta de seguridad jurídica, puesto que se hace depender la respuesta penal, no del hecho cometido, sino de una conducta posterior que puede alterar notablemente el rigor del castigo ${ }^{56}$. Además, desde el punto de vista procesal: a) se rompe la estructura del proceso convirtiendo el inte-

GASCÓN (2010) 82 .

Nieto (2008) 254-255.

Nieto (2008) 181-183.

Rodríguez (2006) 482-483.

Lamarca Pérez, Carmen (1985) Tratamiento jurídico del terrorismo. Madrid: Ministerio de Justicia, p. 349. 
rrogatorio en un método inquisitorial de obtención de pruebas ${ }^{57}$, siempre que el colaborador se encuentre personalmente imputado en la causa. b) se prima un comportamiento contrario a las garantías constitucionales de la presunción de inocencia y del derecho a no declarar contra sí mismo ${ }^{58}$. c) se lleva a cabo una desigualdad procesal y una ruptura del principio de proporcionalidad entre los que colaboran con la autoridad judicial y los se acogen a su derecho de defensa ${ }^{59}$. d) se favorece la confesión falsa contra inocentes. e) puede suponer una inversión de la carga de la prueba para el delatado ${ }^{60}$.

\section{3) EL MOMENTO DE LA IMPUTACIÓN O DE LA FORMALIZACIÓN DE LA INVESTIGACIÓN FRENTE A LA PERSONA JURÍDICA}

Tanto la regulación española, como la regulación chilena, tienen en común que dejan abierta la posibilidad de que la persona jurídica sea juzgada de forma autónoma, esto es, de forma independiente respecto de una persona física, cuando se constate, fehacientemente, que el delito debió, necesariamente, de ser cometido por determinadas personas físicas, siempre que no sea posible determinar qué concreta persona física lo cometió o no sea posible dirigir el procedimiento contra ella. La regulación española exige, a estos efectos, con una redacción bastante defectuosa, que se constate la comisión de un delito que haya tenido que cometerse por quienes ostentan los cargos o funciones de administrador de hecho o de derecho, representante legal o empleado no controlado aun cuando la concreta persona física responsable no haya sido individualizada o no haya sido posible dirigir el procedimiento contra ella -art. 31 bis $2 \mathrm{CP}-$. En el mismo sentido, el art. 5 de la Ley chilena establece una responsabilidad penal autónoma de la persona jurídica cuando la responsabilidad penal individual se haya extinguido por muerte o prescripción de la acción penal, cuando se haya sobreseído provisionalmente el proceso contra la persona natural o cuando no haya sido posible establecer la participación de los responsables individuales, siempre y cuando en el proceso respectivo se demostrare fehacientemente que el delito debió necesariamente ser cometido dentro del ámbito de funciones y atribuciones propias de los sujetos cualificados para provocar la responsabilidad penal de las personas jurídicas, siendo estos sus dueños, controladores, responsables, ejecutivos principales, representantes o

57 Lamarca (1985) 348.

58 Fernández Palma, Rosa (1995) "El terrorista arrepentido en los proyectos de Código Penal de 1992 y 1994", Cuadernos de Politica Criminal, no 57, pp. 915-931, pp. 916-917.

59 López Garrido, Diego (1987) Terrorismo, politica y derecho en España, Reino Unido, República Federal de Alemania, Italia y Francia. Madrid: Alianza, p. 138.

60 Lamarca (1985) 348. 
quienes realicen actividades de administración y supervisión. El establecimiento de una responsabilidad autónoma de la persona jurídica respecto de las personas físicas autoras de los hechos delictivos hace necesario diferenciar dos posibilidades. Por un lado, el supuesto de que el procedimiento se dirija exclusivamente contra una persona jurídica y por otro el supuesto de que el mismo se dirija simultáneamente contra una persona física y contra una persona jurídica, con la particularidad de que esta doble imputación tendrá su origen en los mismos hechos de base que, en todo caso, habrán sido realizados por la persona física imputada.

En el primer supuesto, el hecho de que solo se dirija el procedimiento contra una persona jurídica mientras se reconoce que los hechos, en todo caso, son realizados por una persona física puede deberse a las causas ya señaladas. Por ejemplo, puede ocurrir que la responsabilidad penal de la persona física se haya extinguido por muerte o por haber prescrito el delito ${ }^{61}$, o que esta se haya sustraído a la acción de la justicia, que resulte inimputable o lo que será más habitual, que no sea posible determinar qué concreta persona física ha cometido el delito, precisamente por haberlo hecho desde ese marco de irresponsabilidad organizada que constituyen algunas grandes organizaciones empresariales. En todos estos casos, se procederá a imputar a la persona jurídica siguiendo los criterios generales establecidos en la ley de enjuiciamiento española y en el Código Procesal Penal chileno, que determinan el momento idóneo para ello. Por tanto, habrá que proceder a la imputación judicial de la persona jurídica cuando recaiga una sospecha fundada de que la entidad podría ser penalmente responsable. En relación con esta cuestión, la ordenación española, introducida por la LMAP, ha modificado, una vez más, nuestra centenaria LECrim, introduciendo un nuevo art. 119 que establece que "cuando de acuerdo con lo dispuesto en el art. 118 de esta ley, haya de procederse a la imputación de una persona jurídica, se practicará con ésta la comparecencia prevista en el art. 775”. Lo que interesa ahora es llamar la atención sobre la remisión que este art. hace al art. 118 LECrim $^{62}$, que es el que reconoce la condición de imputado a toda persona determinada contra la que se dirija cualquier actuación procesal de la que resulte la imputación

61 Hay que tener en cuenta en este punto que al entender el artículo 33.7 CP que todas las penas aplicables a las personas jurídicas tienen la condición de graves esto implica que los plazos de prescripción del delito cometido por la persona física y de la responsabilidad penal de la persona jurídica pueden ser distintos.

62 El artículo 118 LECrim establece que "Toda persona a quien se impute un acto punible podrá ejercitar el derecho de defensa, actuando en el procedimiento, cualquiera que éste sea, desde que se le comunique su existencia, haya sido objeto de detención o de cualquiera otra medida cautelar o se haya acordado su procesamiento, a cuyo efecto se le instruirá de este derecho. La admisión de denuncia o querella y cualquier actuación procesal de la que resulte la imputación de un delito contra persona o personas determinadas, será puesta inmediatamente en conocimiento de los presuntamente inculpados". 
de un delito. En definitiva, el legislador español, ha considerado que los presupuestos de la imputación se mantienen, independientemente de que el imputado sea una persona física o una persona jurídica, conformándose con una remisión genérica al precepto que regula la adquisición de la condición de imputado de cualquier persona natural sin tener en cuenta la interdependencia que existe entre la imputación de la persona física autora del delito y la persona jurídica penalmente responsable. Esto supone que la adopción de cualquier medida cautelar contra la entidad, la admisión de una denuncia o querella en su contra ${ }^{63}$, así como cualquier comunicación de la pendencia de un proceso dirigido contra la misma, son actos que implican la asunción por la persona jurídica de la condición de imputada. Este primer supuesto no presenta especiales dificultades. Pero, si se parte de que la imputación implica la atribución, más o menos fundada, de un hecho punible a una determinada persona, a mi modo de ver, resulta insuficiente entender que solo los actos de imputación dirigidos contra la entidad implican la formalización de su imputación, y por ende, el nacimiento de su derecho de defensa. Por el contrario, en ciertos casos, la realización de algunos de esos actos imputatorios, contra determinadas personas físicas, debería implicar también la imputación de la persona jurídica, toda vez que hace recaer una sospecha criminal sobre ella. Esta última afirmación se fundamenta en la necesidad de evitar, en la medida de lo posible, retrasar la imputación de la persona jurídica a la que se atribuye una sospecha de que podría ser penalmente responsable, para intentar avanzar en la investigación a sus espaldas ya que, en tal caso, se estaría retrasando indebidamente el nacimiento de su derecho de defensa.

Volviendo a la redacción de los arts. 31 bis 2 CP y 5 de la Ley chilena, se comprueba que para condenar penalmente a la persona jurídica es necesario constatar -según la redacción del $\mathrm{CP}$ - o demostrar fehacientemente -según la literalidad de la de la Ley 20.393- comisión del delito por determinadas personas físicas. Como consecuencia, si se desciende al grado de sospecha exigible en la fase de instrucción, para proceder a la imputación de una entidad, bastará con sospechar o atribuir más o menos fundadamente la comisión, a esas concretas personas físicas, de algún delito de aquellos susceptibles de generar responsabilidad de las personas jurídicas. La argumentación precedente es la que, a mi modo de ver, subyace en el art. 20 de la Ley chilena que regula la responsabilidad penal de las personas jurídicas, según el cual "Si durante la investigación de alguno de los delitos previstos en el art. $1^{\circ}$-lavado de activos, financiamiento del terrorismo y cohecho- el Ministerio Público tomare conocimiento de la

63 López Yagües (2011) 31, acertadamente, a mi modo de ver que la decisión del juez de proceder a la comprobación de los hechos que se relatan en la denuncia o querella implica su admisión y la consiguiente consideración como imputado del sujeto seńalado como responsable del acto punible. 
eventual participación de alguna de las personas indicadas en el art. $3^{\circ}$-los dueños, controladores, responsables, ejecutivos principales, representantes o quienes realicen actividades de administración y supervisión en la entidad-ampliará dicha investigación con el fin de determinar la responsabilidad de la persona juridica correspondiente".

Es importante dejar claro que, mientras en el ámbito penal, la imputación es el juicio por el que el delito se predica de una persona determinada, en el ámbito procesal, para que exista un imputado, no se requiere la existencia de un delito, sino que basta con la existencia de unos hechos que revistan los caracteres de delito ${ }^{64}$. En palabras del Tribunal Constitucional español, el art. 118 LECrim reconoce la nueva categoría de imputado a todo aquel a quien se impute, más o menos fundadamente, un acto punible 65 . Por tanto, se podría afirmar que, cuando alguna de las personas cualificadas para provocar la responsabilidad penal de una persona jurídica resulta imputada por alguno de los delitos que constituyen la lista tasada de infracciones penales susceptibles de ser atribuidos a tales entes existirá, al menos indiciariamente, la sospecha de que, de tales hechos, se puede derivar responsabilidad criminal de la persona jurídica. Este automatismo, que implicaría el trasvase cuasi automático de la imputación del sujeto individual a la persona jurídica, puede parecer a primera vista inadecuado, o incluso contrario a la presunción de inocencia de la persona jurídica, pero lo cierto es que la regulación penal es parca en el establecimiento de verdaderos criterios de imputación propios y específicos de la entidad, lo cual dificulta el deslinde entre la imputación de la persona física y de la entidad en cuya estructura organizativa se integra aquella, siempre, claro está, que estemos ante un delito de los imputables a las personas jurídicas. Además, en una fase indiciaria, como es la de la imputación o la formalización de la investigación penal, que se mueve en el terreno de la posibilidad ${ }^{66}$, el deslinde será sin duda más difícil de llevar a cabo.

El propósito de las siguientes líneas será establecer los requisitos o las comprobaciones a realizar por el órgano instructor en orden a considerar si los hechos que se imputan a determinada persona física son imputables, más o menos fundadamente, también a la persona jurídica. Para realizar el análisis propuesto es preciso tomar en cuenta que la imputación no puede retrasarse de forma que permita avanzar en la investigación de es-

\footnotetext{
64 SERRA (1969) 673.

65 Tribunal Constitucional Español (Sala Primera), sentencia núm. 44/1985, de 22 de marzo, RTC 1985\44, FJ $3^{\circ}$.

66 En este sentido, Viada López-Puigcerver, Carlos (1950) Lecciones de Derecho Procesal. Madrid: Alpe, p. 471 señala que para la imputación judicial es suficiente la existencia de una mera posibilidad de responsabilidad penal, quedando reservada la probabilidad y la certeza al auto de procesamiento y a la sentencia firme, respectivamente.
} 
paldas al materialmente, y todavía no formalmente, imputado. Es decir, cuando recaiga una sospecha delictiva sobre un sujeto, ya se trate de una persona física o de una persona jurídica, es necesario formalizar la imputación o la investigación contra ella para darle la oportunidad de alegar lo que a su derecho convenga en la correspondiente audiencia. Pero, es necesario buscar el adecuado equilibrio entre una imputación excesivamente temprana, y en consecuencia falta de fundamento, y otra excesivamente tardía que cause indefensión a la persona jurídica imputada ${ }^{67}$. En este sentido, hay que tener presente que una imputación precipitada no es aconsejable ya que la misma tiene connotaciones negativas, afectando a la imagen del imputado. Si se tratase de una persona física la afectación se produciría en su honor o reputación social. En este caso, al ser la imputada una persona jurídica, la imputación podría tener importantes consecuencias en su imagen corporativa ${ }^{68}$ que, en muchas ocasiones, constituye el activo más importante con el que la misma cuenta. Por el contrario, si lo que ocurre es que la imputación se dilata en exceso en el tiempo se estaría restringiendo indebidamente el derecho de defensa de la persona jurídica, que estaría siendo indagada sin oportunidad de contradecir los indicios que la acusación fuese obteniendo contra ella en la investigación. En este punto, se hace necesario recordar que, aun cuando a veces se argumente lo contrario, la imputación, lejos de ser un atentado al derecho de presunción de inocencia del imputado, constituye una garantía de su derecho de defensa ${ }^{69}$. Por tanto, hay que ser cauteloso con los argumentos que apuestan por retrasar la imputación bajo el pretexto de no ensuciar la imagen pública de la organización ${ }^{70}$.

La cuestión a responder es qué tipo de indagaciones ha de realizar el Ministerio Público chileno o el juez de instrucción español, una vez que se ha formalizado la investigación de una persona física cualificada

Tomé Paule, José; García Lubén Barthe, Paloma; Tomé García, José Antonio (2010) Temario de derecho procesal penal, adaptado al nuevo programa de las pruebas selectivas para el ingreso en las carreras judicial y fiscal. $4^{a}$ ed. Madrid: Colex, p. 250.

68 En este sentido, Banacloche Palao, Julio (2011). "La imputación de la persona jurídica en la fase de instrucción”. En Banacloche Palao, Julio; Zarazalejos Nieto, Jesús; Gómez-Jara Díez, Carlos. Responsabilidad penal de las personas jurídicas: aspectos sustantivos y procesales, Madrid: La Ley, pp. 155-193, p. 191, manifiesta que el conocimiento en la opinión pública de que una empresa u organización socialmente reconocida y prestigiosa ha sido imputada en un proceso penal, va a producir un efecto tal de inseguridad, estigmatización y pérdida de imagen, que no es de extrańar que incluso pueda terminar acabando con ella.

69 Ramos (2011) 152. En el mismo sentido se pronuncia Asencio Mellado, José Maa (1993). "El imputado en el proceso penal español". En AA.VV. Cuadernos de Derecho Judicial: La restricción de los derechos fundamentales de la persona en el proceso penal. Madrid: Consejo General del Poder Judicial, pp. 61-78.

70 En contra se muestra BANACLOCHE (2011) 191, quien propone una suerte de conformidad secreta entre la persona jurídica y el Ministerio Público, evitando así formalizar su persecución y su acusación. Opción esta que, en mi opinión, no responde a las exigencias de un proceso público y con todas las garantías. 
para generar la responsabilidad penal de la persona jurídica, en orden a ratificar la verosimilitud de la imputación respecto de la persona jurídica. Para ello, tomaremos como punto de partida la regulación positiva establecida en los arts. 31 bis CP y 3 de la Ley 20.393, de los que se extraerá la respuesta a la cuestión planteada. El apartado primero del art. 31 bis CP establece que "en los supuestos previstos en este Código, las personas jurídicas serán penalmente responsables de los delitos cometidos en nombre o por cuenta de las mismas, y en su provecho, por sus representantes legales y administradores de hecho o de derecho En los mismos supuestos, las personas juridicas serán también penalmente responsables de los delitos cometidos, en el ejercicio de actividades sociales y por cuenta y en provecho de las mismas, por quienes, estando sometidos a la autoridad de las personas físicas mencionadas en el párrafo anterior, han podido realizar los hechos por no haberse ejercido sobre ellos el debido control atendidas las concretas circunstancias del caso". Por su parte, la ley chilena, con un precepto similar en cuanto al contenido y en cuanto a la estructura, establece que "Las personas juridicas serán responsables de los delitos señalados en el art. $1^{\circ}$ que fueren cometidos directa e inmediatamente en su interés o para su provecho, por sus dueños, controladores, responsables, ejecutivos principales, representantes o quienes realicen actividades de administración y supervisión, siempre que la comisión del delito fuere consecuencia del incumplimiento, por parte de ésta, de los deberes de dirección y supervisión. Bajo los mismos presupuestos del inciso anterior, serán también responsables las personas juridicas por los delitos cometidos por personas naturales que estén bajo la dirección o supervisión directa de alguno de los sujetos mencionados en el inciso anterior". Hasta aquí se podría considerar que los modelos de imputación penal español y chileno son prácticamente idénticos, pero la regulación chilena a continuación añade que "Se considerará que los deberes de dirección y supervisión se han cumplido cuando, con anterioridad a la comisión del delito, la persona juridica hubiere adoptado e implementado modelos de organización, administración y supervisión para prevenir delitos como el cometido". Además, "las personas juridicas no serán responsables en los casos que las personas naturales indicadas en los incisos anteriores, hubieren cometido el delito exclusivamente en ventaja propia o a favor de un tercero".

En vista de la dependencia que presenta la responsabilidad penal de las personas jurídicas respecto de las personas físicas que actúan en su seno, se puede afirmar que, si la autoridad encargada de la instrucción sospecha que un representante, administrador de hecho o de derecho, dueño, directivo, ejecutivo, controlador o supervisor de la entidad ha cometido uno de esos delitos tasados, lo cual debiera implicar la imputación de esa persona física, y además, por determinadas circunstancias de tiempo y espacio puede verosímilmente entenderse que el delito se ha cometido en el marco de su actuación en el seno de la persona jurídica, parece 
que cuenta con elementos más que suficientes para imputar también a esta última ${ }^{71}$, salvo que sospeche fundadamente que la comisión del delito en cuestión se ha producido en provecho exclusivo de la persona física, incluso con perjuicio evidente para la entidad.

La exigencia de que concurra un defecto de organización, como aporte propio de la persona jurídica, para evitar una responsabilidad objetiva o por el hecho de otro, que aparece expresamente dispuesta en la regulación chilena y algo más oculta en la española ${ }^{72}$, no cambiaría, a mi modo de ver, la tesis propuesta. Ni siquiera el hecho de que la implementación en la organización de un programa de cumplimiento efectivo o de medidas eficaces para prevenir y descubrir los delitos, antes de su comisión, se considere como una eximente ${ }^{73}$, modificaría las conclusiones alcanzadas. El motivo radica en que la comprobación de tales extremos hará, en todo caso, necesaria una cierta actividad instructora, o incluso probatoria, por lo que no podrá apreciarse de forma previa a la formalización de la investigación frente a la entidad. A mi modo de ver, tal defecto de organización requiere llevar a cabo una serie de diligencias de investigación que permitan conocer aspectos tales como la estructura or-

71 Este razonamiento parece estar presente en la redacción del artículo 20 de la Ley Chilena no 20.393, que dispone que "Si durante la investigación de alguno de los delitos previstos en el artículo $1^{\circ}$, el Ministerio Público tomare conocimiento de la eventual participación de alguna de las personas indicadas en el artículo $3^{\circ}$, ampliará dicha investigación con el fin de determinar la responsabilidad de la persona juridica correspondiente".

72 Aunque el CP español no exige expresamente que haya un defecto de organización cuando el delito es cometido por un representante legal o administrador de hecho o de derecho de la entidad, la doctrina sostiene que una lectura constitucionalmente legítima del citado precepto obliga a exigir tal circunstancia. Entre otros, Fernández Teruelo, José Antonio (2010). "Algunas consideraciones críticas sobre el nuevo modelo de responsabilidad penal de las personas jurídicas introducido en la LO 5/2010”, Revista de Derecho Penal, no 31, publicado en septiembre de 2010, pp. 43-72, p. 60.

73 Esta causa de exención de responsabilidad también aparece establecida de forma expresa en la regulación chilena, mientras que en la regulación española se podría deducir de la circunstancia atenuante consistente en establecer un programa de cumplimiento tras la comisión del delito y antes del juicio oral. En este sentido, parte de la doctrina entiende que, si la adopción de tal modelo es anterior a la comisión del delito, la persona jurídica no debería responder, por exigencia del principio de culpabilidad dado que su conducta no sería penalmente reprochable y, además, por el escaso efecto preventivo que tendría penar a una persona jurídica que ha sido totalmente diligente en las tareas de prevención delictiva. En este sentido se manifiestan, entre otros, Gómez-Jara Díez, Carlos (2009). "La atenuación de la responsabilidad empresarial en el Anteproyecto de Código Penal de 2008: los compliance programs y la colaboración con la administración de justicia”. En Casanueva Sanz, Itziar et al. El anteproyecto de modificación del Código Penal de 2008: algunos aspectos. Bilbao: Universidad de Deusto, pp. 221-289, pp. 270-274; De la Mata Barranco, Norberto (2010). "La responsabilidad penal de las personas jurídicas". En Juanes Peces, Ángel (director) Reforma del Código Penal. Perspectiva económica tras la entrada en vigor de la Ley Orgánica 5/2010 de 22 de junio. Situación jurídico-penal del empresario, Madrid: El Derecho, pp. 67-89, p. 77; Carbonell Mateu, Juan Carlos; Morales Prats, Fermín (2010). "Responsabilidad penal de las personas jurídicas". En Álvarez García, Francisco Javier; González Cussac, José Luis (directores), Comentarios a la reforma penal de 2010. Valencia: Tirant lo Blanch, pp. 55-84, p. 76. 
gánica de la entidad, la forma de organización funcional de la misma, los procesos de toma de decisiones por los que se rige, los flujos de poder y de información que tienen lugar en su seno, los procesos productivos que desarrolla y los mecanismos de prevención y detección de riesgos delictivos o de otra naturaleza. Pero, la comprobación de estos extremos u otros análogos será siempre posterior a la existencia de una sospecha criminal contra una persona jurídica determinada. Luego, siendo tal sospecha el presupuesto de la imputación, que al mismo tiempo es necesaria para poder acordar diligencias de investigación restrictivas de derechos, en orden a comprobar que efectivamente concurre un defecto de organización, previamente habrá que proceder a la formalización de la investigación contra la persona jurídica ${ }^{74}$, esto es, a su imputación formal a través de la información de los hechos que se le imputan y de su comparecencia mediante un representante, a efectos de que la entidad pueda alegar lo que a su derecho convenga.

Obviamente, tanto la imputación como la formalización de la investigación son juicios provisionales, puesto que pueden ser desvirtuados en cualquier momento por datos derivados de la investigación o de la práctica de la prueba que desvanezcan las sospechas que determinaron la atribución inicial de los hechos delictivos ${ }^{75}$ a la entidad. Si esto ocurre durante la instrucción se deberá proceder a la desimputación ${ }^{76}$ de la entidad, finalizada la instrucción se debería proceder al sobreseimiento y, asimismo, si durante el juicio oral, como consecuencia de la práctica de la prueba, no se logra el convencimiento del juzgador sobre la culpabilidad del sujeto en cuestión, esto provocará su libre absolución. También es necesario no perder de vista que el juez de instrucción en España, y el Ministerio Público en Chile, gozan de un amplio margen de discrecionalidad en la valoración, o provisional ponderación, de esa atribución de un hecho punible a persona determinada, que constituye la imputación $\mathrm{n}^{77} \mathrm{o}$ la formalización de la investigación respectivamente, por lo que finalmente les corresponderá a tales autoridades tomar la decisión de si, habiendo

74 Según Banacloche (2011) 180, la imputación debe producirse o bien cuando se acrediten actuaciones punibles realizadas por directivos de la entidad en beneficio de la misma, o bien porque aparece que la sociedad carecía de los protocolos adecuados para evitar las conductas delictivas realizadas por sus empleados. A mi modo de ver, esta afirmación no es correcta, ya que en esta fase no debería hablarse propiamente de acreditación sino tan solo de una posibilidad indiciaria, además cuando dice el autor que "aparece que la sociedad carecía de protocolos", usando el verbo aparecer se oculta que para comprobar o indagar sobre este hecho es preciso realizar ciertas diligencias de investigación, y que no se trata de una cuestión que se pueda verificar, siquiera de forma provisional, con una aparición espontánea.

75 SERRA (1969) 676.

76 Término acuñado por Ramos (2011) 155, para referirse a la necesidad de que existe un acto análogo a la imputación que de publicidad a la neutralización o desvanecimiento de la sospecha que provocó una imputación.

Del Olmo (1999) 33. 
sido imputada una persona física, administrador o representante de una persona jurídica, por un delito susceptible de generar responsabilidad penal para esta, coimputa o no a la entidad.

En definitiva, el juicio de imputación, que se realiza respecto de la persona física que comete el delito del que podría derivarse responsabilidad penal para la persona jurídica, se traslada de forma cuasi automática a esta última sin que esto implique, necesariamente, que nos encontremos ante una responsabilidad objetiva o por hecho ajeno. El motivo de esa traslación se fundamenta en tres razones básicas. En primer lugar, se asienta en la naturaleza de la fase inicial del proceso en la que se desarrolla la imputación, en la que los grados de certidumbre son por definición bajos, bastando una posibilidad, sospecha o verosimilitud de la atribución de un hecho punible a persona determinada para que la misma sea imputada. Esa laxitud o falta de certeza es inherente al propio instituto de la imputación ya que se trata del primer juicio de la, denominada por CARNelutTi $^{7}$, escala de juicios. Para este autor, la escala de juicios proviene del hecho de que el proceso penal constituye, en sí mismo, una pena. Por tanto, antes de poder castigar a un hombre es preciso condenarlo; pero antes de condenarlo preciso es juzgar si puede ser sometido a debate; y antes de someterlo al juicio acerca de la posibilidad de someterlo a debate hay todavía un juicio anterior: el juicio de imputación ${ }^{79}$. En segundo lugar, el hecho de que en esta fase preliminar se haga extremadamente difícil diferenciar la imputación de la persona física de la imputación de la persona jurídica se debe a que el elemento que fundamenta la responsabilidad propia de la persona jurídica, el defecto de organización, entendido como incumplimiento de los deberes de dirección y supervisión, es un elemento normativo complejo, que requiere, por tanto, una ponderación o valoración judicial más profunda y de naturaleza distinta que la que se realiza en la formalización de la investigación o en la imputación. Por otra parte, como ya se expuso, la comprobación, siquiera indiciaria, de que concurre tal defecto de organización implicará cierta intromisión en la esfera interna de la persona jurídica y, por lo que, en virtud del respeto al nuclear derecho de defensa, se requerirá su previa imputación. Y en tercer lugar, se debe a la interdependencia que existe entre la responsabilidad penal de la persona jurídica y la de las personas físicas que actúan por ella, dado que ambas se asientan en una base fáctica parcialmente común.

A modo de ejemplo, piénsese en el supuesto de que un administrador de una sociedad, administrador único de la misma, para simplificar el supuesto, sea detenido e imputado por la comisión de un delito consis-

\footnotetext{
78 Carnelutti, Francesco (1961) Cuestiones sobre el proceso penal. Traducción de Santiago Sentís Melendo. Buenos Aires: Ediciones jurídicas Europa-América, p. 135. 
tente en la llevanza de doble contabilidad para ocultar o simular la verdadera situación de la empresa -art. 310. b) CP-. Tratándose de un delito susceptible de generar responsabilidad penal de las personas jurídicas -ex art. 310 bis $\mathrm{CP}-\mathrm{y}$, siendo el mismo cometido por una persona idónea para ocasionar tal atribución de responsabilidad -ex art. 31 bis $\mathrm{CP}-$, solo restará indagar si hay indicios o muestras evidentes de que el administrador único actuó exclusivamente en su provecho personal y en perjuicio de la sociedad. Si este último extremo requiere para su constatación de cierta actividad instructora, que tenga como objeto-sujeto de investigación a la persona jurídica, será necesario previamente formalizar la investigación contra la entidad dado que la sospecha ya habrá recaído sobre ella, y solo posteriormente se podrán iniciar las actividades indagatorias tendentes a confirmar esa imputación provisional o a sobreseer el proceso contra la persona jurídica, en su caso. Lo que se pretende poner de manifiesto con este ejemplo es que, en determinados casos, la imputación de una persona física debiera conllevar también la imputación de una persona jurídica. Por tanto, a los actos que el art. 118 LECrim les atribuye la cualidad de presupuestos de la imputación habrá que añadir, según los casos, ciertos actos que aunque no se dirijan formalmente contra la persona jurídica, implican atribuirle más o menos fundadamente una participación en ciertos hechos punibles, lo cual debería conllevar una imputación y, por ende, el nacimiento del derecho de defensa también para la persona jurídica. De no seguirse tal interpretación, e imputar únicamente a la persona física, se podría llegar a una situación de indefensión para la persona jurídica, que estaría siendo privada de su derecho a defenderse. Esta rechazable situación podría empeorar en el caso de que la persona física imputada, administrador de la sociedad, intentase, atenuar su responsabilidad, civil y penal, coimputado a la persona jurídica, lo cual pone de manifiesto la necesidad de imputar a esta última para permitirle desplegar su estrategia defensiva. Luego, cabe concluir que, por regla general, la imputación de ambos sujetos deberá ser simultánea.

En este sentido, resulta de todo punto acertado el art. 20 de la Ley chilena que obliga a ampliar la investigación a la persona jurídica para el caso de que, en el marco de la averiguación de un delito imputable a la persona jurídica, se constate la participación en el mismo de un sujeto cualificado para generar la responsabilidad penal de la entidad. Sin embargo, la conclusión alcanzada se contrapone, en cierta medida, a lo establecido en el art. 22 de la misma Ley que establece que será requisito previo para formalizar la investigación contra la persona jurídica haber formalizado la investigación contra alguna de las personas físicas señaladas en el art. 3 del mismo texto legal, salvo que nos encontremos en un supuesto de responsabilidad autónoma de la entidad -art. 5 de la Ley 20.393-. Por las razones expuestas, entiendo que la formalización de la investigación de la persona física y la persona jurídica, cuando ambas vayan a ser juzgadas conjunta- 
mente, debe ser simultánea y no sucesiva en el tiempo, ya que la sospecha sobre la persona individual se traspasa a la entidad y ambas deben tener garantizado desde un primer momento el derecho a ser oídas y a defenderse de los indicios delictivos presentados contra ellas, incluso esgrimiendo estrategias defensivas contradictorias. La imputación sucesiva de ambos sujetos - regulada en el art. 22 de la Ley chilena- presenta la ventaja de obligar al Ministerio Público a determinar, antes de imputar a la entidad, qué concretas personas físicas han cometido el delito, de tal forma que es necesario agotar las posibilidades de investigación, en orden a individualizar las responsabilidades en la medida de lo posible, antes de señalar a la entidad como posible culpable. Pero también presenta el inconveniente de que puede suponer un retraso indebido en el nacimiento del derecho de defensa de la persona jurídica, aunque este problema se soluciona, en gran medida, con el derecho reconocido a la persona jurídica consistente en pedir que se formalice la investigación en su contra -art. 21 de la Ley 20.393 en relación con los arts. 93 y $186 \mathrm{CPP}-$.

\section{4) LA REPRESENTACIÓN DE LA PERSONA JURÍdiCA EN EL PROCESO PENAL}

La última cuestión objeto de análisis será la representación de la persona jurídica en el proceso penal. Más complejo que el problema de en qué condición interviene la persona jurídica en el proceso es determinar cómo se produce esa intervención. Es decir, de qué forma se ejercitan esos derechos y garantías que hemos atribuido en abstracto a la persona jurídica imputada. Esta es una cuestión clave, tanto en su dimensión teórica como en su dimensión práctica. En un plano teórico la respuesta que se dé a esta pregunta responderá a la concepción que se tenga de la persona jurídica y vendrá a determinar la amplitud y los límites con los que se reconocen a la persona jurídica los derechos y garantías del imputado, en particular el derecho de defensa, en su doble vertiente de defensa técnica y autodefensa. Desde un punto de vista práctico, esta cuestión permitirá al juez o tribunal determinar con quién debe entenderse en la práctica de las diligencias de investigación, en los interrogatorios, en el juicio oral, así como en todos aquellos trámites que deban realizarse en presencia del imputado.

La persona jurídica, por su propia naturaleza, actúa en el tráfico jurídico a través de determinadas personas físicas. Es por todos sabido que la persona jurídica es un ente capaz de ser sujeto de derechos y deberes, así como apto para ser centro de imputación de efectos jurídicos ${ }^{80}$. En tal

\footnotetext{
80 Bacigalupo Sagesse, Silvina; Sánchez-Vera Gómez-Trelles, Yolanda (2005) Cuestiones prácticas en el ámbito de los delitos de empresa. Perspectivas de la dimensión jurisprudencial. Barcelona: Ediciones Experiencia, p. 60.
} 
sentido el Código Civil español, en su art. 38, establece que "las personas juridicas pueden adquirir y poseer bienes de todas clases, asi como contraer obligaciones y ejercitar acciones civiles o criminales". Pero, lo cierto es que la falta de corporeidad de las personas jurídicas exige que sea una persona natural la que, en representación de tales entes colectivos, negocie, suscriba los contratos, custodie los bienes, promueva las distintas clases de acciones legales y en fin, realice todos aquellos actos que requieren de la intervención humana para materializarse en la realidad, aun cuando los efectos jurídicos sean imputados de forma directa e inmediata a la persona jurídica. El problema de la determinación de quien haya de actuar en nombre de la persona jurídica en el proceso penal se complica si se tiene en cuenta que es posible, y aún probable, que junto a la persona jurídica aparezca como imputada una persona física, y que esta sea representante orgánico o apoderado de la misma. Obviamente, esto se debe a que la persona jurídica responde penalmente por hechos cometidos por sus administradores de hecho o de derecho o por sus representantes legales. Por tanto, de esos hechos se derivarán responsabilidades penales para ambos sujetos, persona física y persona jurídica, entre los que puede surgir un conflicto de intereses.

\section{1) LA SITUACIÓN DE CONFLICTO DE INTERESES ENTRE EL REPRESENTANTE PERSONALMENTE IMPUTADO Y LA PERSONA JURÍDICA}

Pudiera ocurrir que los intereses del administrador imputado junto con la persona jurídica fuesen coincidentes si su estrategia defensiva consistiese en negar la existencia del delito base, es decir, del delito cometido por una persona física, de entre aquellas que pueden hacer surgir la responsabilidad penal de las personas jurídicas. En definitiva, si se niega o se contraprueba la existencia de un delito de blanqueo de capitales o una defraudación tributaria, por poner un ejemplo concreto, no nacerá responsabilidad para ninguno de los dos sujetos. Pero, fuera de este supuesto, en el cual la estrategia defensiva de ambos sujetos coincide, la imputación conjunta de la sociedad y de su administrador constituye una situación susceptible de hacer surgir, de forma previsible, intereses contrapuestos ${ }^{81}$ entre administrador y sociedad. En este sentido, se puede afirmar que existe un conflicto de intereses potencial entre el administrador y la sociedad cuando ambos están imputados por un delito, toda vez que puede ocurrir que lo que es conveniente para la sociedad, básicamente colaborar en la investigación, puede no serlo para su representante, que puede verse

\footnotetext{
81 Gascón (2010) 62, afirma que por la existencia de un claro conflicto de intereses entre la persona física imputada y la persona jurídica ha de excluirse también que ambas sean defendidas por el mismo abogado.
} 
perjudicado por los resultados de esa colaboración ${ }^{82}$. Este posible conflicto de intereses, que debería suponer la incompatibilidad de roles, de tal forma que el representante personalmente imputado no pueda desarrollar el papel de representante de la persona jurídica en el proceso, es abordado de distinta forma en los diversos ordenamientos.

En Italia se establece que la persona jurídica será representada en el proceso por su representante legal, siempre y cuando esa persona no esté personalmente imputada por el delito presupuesto -art. 39.1 D. Lgs. 231-. En tal caso la persona jurídica tendría la libertad de designar a quien crea conveniente para su representación en el proceso, y por ende para desarrollar sus facultades autodefensivas. De no hacerlo, o en el caso de que el representante designado no comparezca, el ente quedaría constituido en el proceso con el abogado de confianza designado por la entidad -art. 39.4 D. Lgs. 231-, o en su caso, con el designado de oficio -art. 40 D. Lgs. 231-. En definitiva, si ha de haber un sujeto que represente a la persona jurídica en el proceso penal, subrogándose en su condición de imputado a los efectos de ejercitar el derecho de defensa que corresponde al ente, no parece en absoluto adecuado que esta persona física pueda ser uno de los directivos, con poder de representación, imputados en la causa. En este sentido, y partiendo de la importancia fundamental que tiene el derecho de defensa en el proceso penal, parece que la solución del ordenamiento italiano al respecto, partiendo de una incompatibilidad ipso iure que impide que la representación de la persona jurídica en el proceso puede ser encomendada a una persona física imputada en el mismo, resulta acertada ${ }^{83}$.

En Chile no se plantea expresamente un supuesto de incompatibilidad como solución al potencial conflicto de intereses descrito, sino que es el fiscal el que individualiza al representante legal que va a actuar por la persona jurídica imputada en el proceso penal, solicitando al juez de garantías que el mismo sea citado para una primera comparecencia -art. 22 Ley 20.393- . Por lo tanto, no hay libertad de elección por parte de la persona jurídica, sino que es el Ministerio Público el que determina quién actuará por la persona jurídica en el marco del enjuiciamiento, con lo que será el propio Ministerio, con su decisión, el que evitará, en la medida de lo posible, el conflicto de intereses subyacente, designando como defensor de la entidad a alguno de sus representantes legales que no se encuentre personalmente imputado en la causa. Pero es posible que todos los representantes legales de la entidad se encuentren imputados, sin que la legislación chilena ofrezca una solución al conflicto de intereses que surgiría en

BANACLOCHE (2011) 170-171.

83 El artículo 39.1 D. Lgs. 231/2001 italiano establece, a este respecto, que el ente participa en el procedimiento penal a través de su representante legal, salvo que este se encuentre imputado por el delito del que depende el ilícito administrativo. 
tal caso. Se echa en falta que, tal como ocurre en el derecho italiano o en el francés, se prevea la posibilidad de reemplazar por un tercero al representante legal de la persona jurídica cuando el procedimiento se dirigiera también contra él.

En España el Proyecto de la LMAP preveía que, tanto la primera comparecencia, como otras diligencias de investigación o prueba que requiriesen la presencia física del imputado, fuesen llevadas a cabo a través del abogado designado por la empresa, o a falta de tal designación, por el abogado de oficio. Aquella regulación, dudosamente constitucional, partía de la irrelevancia de la asistencia de un representante especialmente designado por la entidad, de tal forma que su presencia en las distintas fases procesales era meramente testimonial y su ausencia no impedía, en ningún caso, la realización de las actuaciones judiciales pertinentes, y la prosecución del proceso, hasta su finalización. La LMAP, que resultó finalmente aprobada y modificó la LECrim, le otorga mayor relevancia a la presencia de un representante especialmente designado por la entidad para ocupar el espacio autodefensivo que le es propio. Sin embargo, si nos centramos en el tratamiento que recibe la cuestión del conflicto de intereses latente entre la entidad y el representante personalmente imputado, se puede afirmar que el Proyecto resultaba, en este punto, más garantista. Ni la versión actualmente vigente ni el Proyecto contemplan incompatibilidad alguna hasta llegar a la fase de juicio oral, por tanto para el acto de la primera comparecencia -art. 119 en ambas versiones-, para la práctica de las diligencias de investigación y prueba anticipada -art. 120 en ambas versiones-, así como para la declaración indagatoria que tiene lugar en esa primera comparecencia -solo prevista en la regulación vigente, en el art. 409 bis, en vista de que el Proyecto la consideraba incompatible con la naturaleza de la persona jurídica- no se prevé incompatibilidad alguna, pudiendo desarrollar el papel de representante de la entidad, cualquiera con poder para ello, incluso el personalmente imputado en la causa. Sin embargo, al llegar al juicio oral el representante de la entidad, que ocuparía en la sala el lugar reservado al acusado, no podría ser, según el Proyecto, quien hubiera de declarar como testigo o quien debiera tener cualquier otra intervención en la práctica de la prueba, consideración esta última en la que quedarían incluidos los peritos y los coimputados cuya declaración hubiera sido propuesta y admitida como prueba. En definitiva, con la regulación del Proyecto, el representante de la persona jurídica imputado en la causa no podría representar a la entidad durante el juicio oral por la imposibilidad de compatibilizar su rol de imputado, en su faceta de medio probatorio, con la representación de la entidad. Esta incompatibilidad, por lo tanto, salvaría el conflicto de intereses, al menos en el caso de que ambos sujetos, persona física y jurídica, estuviesen imputados en el mismo proceso. La versión final de la LMAP limitó la incompatibilidad con el rol de representante de la entidad en el juicio oral a quien hubie- 
ra de declarar como testigo, abriendo por tanto la posibilidad de que el representante personalmente imputado pudiese actuar simultáneamente como imputado y como representante de la persona jurídica coimputada. Este es el fundamento de la afirmación de que el Proyecto era, en este punto, más garantista que la versión finalmente aprobada de la LMAP. Por otra parte, esta incompatibilidad, para actuar como representante de la entidad en el proceso, limitada a quien haya sido propuesto y admitido como testigo, parece responder más bien a las necesidades de la acusación que a las garantías del derecho de defensa, toda vez que se impide que sea nombrado como representante, gozando por tanto del derecho a no declarar, a quien puede conocer los hechos de forma directa, que será llamado como testigo para que la acusación se aproveche de tal conocimiento en orden a practicar una prueba de cargo suficiente para desvirtuar la presunción de inocencia de la entidad. Desde una óptica garantista hubiera resultado más correcto seńalar que no puede ser llamado como testigo ningún representante legal de la persona jurídica. Solución, por otra parte, más acorde con lo previsto en el ordenamiento chileno cuando establece que los derechos del imputado -entre ellos el derecho de defensa, de asistencia letrada, el derecho a ser oído, a no declarar contra sí mismo o a usar la declaración como medio de descargo- pueden ser ejercidos por cualquier representante de la entidad.

\section{2) LA DETERMINACIÓN DEL REPRESENTANTE DE LA PERSONA JURÍDICA EN EL PROCESO}

La cuestión de quién encarna, en sustitución de la persona jurídica, la figura del imputado en el proceso, en orden a que la misma pueda ejercitar sus derechos y hacer valer las garantías que le corresponden como imputada, tiene una importante repercusión práctica que además tampoco encuentra una solución unánime en el Derecho comparado, ni siquiera en la doctrina española. Prueba plena de la relevancia de resolver este extremo la constituye el hecho de que, los distintos ordenamientos nacionales que reconocen la responsabilidad penal de las personas jurídicas, por escueta que sea su regulación procesal, regulan específicamente esta cuestión. También la doctrina española se ha encargado de estudiar la posible solución de este asunto, pero sin que se pueda atisbar, todavía, un principio de acuerdo o acercamiento entre las diversas posturas de los distintos autores ${ }^{84}$.

84 Las propuestas doctrinales sobre esta cuestión ante la ausencia inicial de regulación legal fueron de lo más variadas: desde el nombramiento de un defensor judicial, que tomara como referencia la figura del administrador concursal (en este sentido, se pueden ver las propuestas de Hernández García (2010) 10-13; Gascón (2010) 62) hasta el requerimiento por parte del Juez de Instrucción para que la sociedad convocase una Junta en la que nombrase a un 
En Chile la cuestión de la representación de la persona jurídica en el marco del proceso penal, se resuelve el art. 22 de la Ley 20.393, el cual dispone que será el Ministerio Público el que solicitará del juez de garantías la citación del representante legal, previa individualización del mismo en la solicitud de audiencia de formalización de la investigación dirigida contra la persona natural que ha cometido el delito del que se deriva responsabilidad para la persona jurídica. Por su parte, el art. 23 del mismo cuerpo legal dispone que si el representante legal, citado por el juez a petición del Ministerio, no comparece injustificadamente, puede llegar a ser arrestado hasta la celebración de la audiencia, que deberá celebrarse en un plazo máximo de veinticuatro horas desde que tuvo lugar la privación de libertad. Además, el mismo precepto establece que, para el caso de que el representante legal no fuere habido, el fiscal solicitará al tribunal que designe a un defensor penal público, que realizará la función de un curador ad litem, en representación de la persona jurídica, pudiendo la persona jurídica designar, en cualquier momento, a un defensor de su confianza que le sustituya. En este último caso bastará, para la celebración de una audiencia judicial que, de ordinario requeriría la presencia del imputado, con la presencia de un defensor penal público, con funciones de curador ad litem, o del defensor de confianza, en su caso.

En España la regulación positiva contenida en la LECrim, tras la modificación producida en la misma por la LMAP, deja libertad a la entidad para nombrar a un representante para actuar en juicio en su nombre, y ocupar así el espacio autodefensivo que la persona jurídica, dada su falta de corporeidad, no pueda cubrir. Este representante especialmente designado no tiene por qué cumplir ningún requisito específico, salvo haber sido apoderado por la entidad para ejercer su representación en el proceso. Pero tal apoderamiento podría recaer, en principio, sobre cualquier persona, o incluso sobre varias personas sucesivamente, ya que nada impide el cambio de representante durante la pendencia del proceso ${ }^{85}$. La única limitación que se establece es que para actuar en el juicio oral, no se podrá designar como representante, a quien haya de intervenir en la práctica de la prueba, en calidad de testigo -art. 786 bis 1 in fine-.

En definitiva, mientras que en la regulación española, la designación de un representante para actuar en juicio por la persona jurídica le corresponde a la propia entidad, que será requerida por el juez de instrucción a tal efecto -art. 119. 1. a) LECrim-, en Chile es el Ministerio Público el

representante ad hoc para actuar en el proceso (Propuesta de Portal Manrubia, José (2010) "La persona jurídica ante la jurisdicción penal tras la última reforma del Código Penal" Revista Aranzadi Doctrinal, no 6, publicado en octubre de 2010, pp. 167-182).

85 Velasco NúŃnz, Eloy (2012) "Responsabilidad penal de las personas jurídicas: aspectos sustantivos y procesales", Diario La Ley, no 7883, 19 de junio 2012. Disponible en: http:// p88-127.0.0.1.accedys.udc.es/accedix0/sitios/control/0incrustat.php?aplicacion=10031 
encargado de individualizar al representante legal de la persona jurídica que actuará en su nombre en el proceso -art. 22 in fine Ley 20.393-. Por otra parte, en Espańa, la falta de designación del representante por parte de la entidad no impide la sustanciación del procedimiento con el abogado y el procurador, sean estos designados por la persona jurídica o, en su defecto, designados de oficio - art. 119.1.a) LECrim-. En coherencia con esto la LECrim viene a establecer la irrelevancia de la inasistencia, en las distintas actuaciones procesales, del representante especialmente designado. En este sentido, el art. 119.1 b) del citado texto legal establece que la inasistencia del representante a la primera comparecencia, en la que se produce la imputación de la persona jurídica, determinará que la misma se practique con el abogado de la entidad. Algo similar dispone el art. 120.2 LECrim para la inasistencia del representante a las diligencias de investigación o prueba anticipada que requieran o autoricen la presencia del imputado, en cuyo caso se sustanciarán las mismas con el abogado defensor. En cuanto a la declaración indagatoria que tendrá lugar, normalmente en la primera comparecencia, la inasistencia del representante especialmente designado determinará que se tenga por celebrado el acto, entendiéndose que la persona jurídica se acoge a su derecho a no declarar -art. 409 bis in fine LECrim-. Y otro tanto se establece para el caso de incomparecencia del representante al juicio oral disponiéndose, de forma rotunda, que tal eventualidad, en ningún caso impedirá la celebración de la vista, que se llevará a cabo con la presencia del Abogado y el Procurador de la persona jurídica. La regulación resulta, en este punto similar a la italiana, de tal forma que se garantiza en todo caso la defensa técnica y se deja libertad a la entidad para designar representante. En el caso de que la entidad no cumpla con tal carga la consecuencia será la pérdida de las posibilidades de autodefensa ${ }^{86}$.

En el ordenamiento chileno, por el contrario, el art. 23 de la Ley 20.393 dispone que si citado para comparecer a una audiencia ante el tribunal, el representante legal de la persona jurídica, previamente individualizado por el Ministerio Público, no se presentare injustificadamente, el tribunal podrá ordenar que sea arrestado hasta la realización de la audiencia. Esta regulación se asemeja más a la del ordenamiento francés que, en el art. 706-44 Code de Procédure Pénale, establece que contra el

86 En este sentido, Fidelbo, Giorgio (2010), "Le atribución del giudice penale e la partecipazione dell'ente al processo". En Bastia, Paolo et al. Lattanzi, Giorgio (director), Reati e responsabilità degli enti: guida al D. lgs. 8 giugno 2001, n. 231. 2 ed. Milano: Giufrè Editore, pp. 435-487, pp. 466-468, dice que la declaración de constitución, individualizando a un representante encargado de la defensa material del ente en el proceso en los términos del art. 39 del D. Lgs. n 231, es una carga para la persona jurídica. Su falta no le priva de la condición de sujeto del procedimiento que tiene desde que existe noticia del ilícito administrativo dependiente del delito, pero reduce su espacio de autodefensa, aunque no condiciona ni limita la defensa técnica. 
representante podrán acordarse las mismas medidas coercitivas que cabe acordar frente a los testigos, por lo que se le podrán imponer multas y se le podrá obligar a comparecer coactivamente ante su inasistencia injustificada -art. 109 Code de procédure pénale-. ${ }^{87}$. En todo caso, la regulación chilena prevé que si el representante, a pesar de la orden de arresto, no fuera habido, se encargará el tribunal de designar un defensor penal público que actuará como curador ad litem, lo que también recuerda a la posibilidad establecida en el ordenamiento francés de nombrar un mandataire de justice -art. 706-43 Code de procédure pénale-.

Se puede afirmar en definitiva, que las regulaciones chilena y francesa establecen un estatus para el representante de la persona jurídica de elevada sujeción, de tal forma que el mismo puede ser conducido por la fuerza ante la autoridad pública. Esto no nos permite, por sí solo, afirmar si su condición es más próxima a la del imputado o a la del testigo, dado que ambos pueden ser normalmente obligados a comparecer ante la autoridad judicial. Por otra parte, de esta mayor sujeción se podría deducir que, tanto en Chile como en Francia, se otorga mayor relevancia a la autodefensa de la persona jurídica, dándole mayor importancia a su personación en juicio a través de una persona física. Por otro lado, estarían las regulaciones espańola e italiana, en las que el representante no puede ser objeto de arresto ni de otras medidas cautelares personales, lo cual resulta coherente con la posibilidad de que el procedimiento se desarrolle hasta su conclusión, ante la ausencia del mismo, tan solo con el abogado de la entidad, perdiendo con ello la posibilidad de ejercitar las facultades propias de la autodefensa. En este sentido, se puede afirmar que mientras la presencia del representante es un deber jurídico en los ordenamientos chileno y francés, en las regulaciones española e italiana se configura más bien como una carga para la entidad, que si no es asumida por la misma, provoca la restricción de sus posibilidades autodefensivas, eso sí, manteniendo intactas sus posibilidades de defensa técnica.

\section{CONCLUSIONES}

1. La reciente introducción de un auténtico régimen de responsabilidad penal de las personas jurídicas, tanto en Chile como en España, ha venido impulsada, aunque no impuesta, desde instancias supranacionales como la OCDE y la Unión Europea respectivamente, que a su

87 A la vista de la regulación del ordenamiento francés parece que la condición del representante de la entidad en juicio se asemeja a la de un testigo, pero la jurisprudencia ya se ha percatado de la diferencia sustancial que existe entre ambas figuras y ha creado un estatus para este sujeto que se encuentra a caballo entre el testigo y el imputado. En este sentido vid. Fidelbo (2010) 490. 
vez se han visto notablemente influenciadas por las regulaciones del common law en las que, tradicionalmente, ha existido la posibilidad de exigir responsabilidad penal a las entidades colectivas.

2. Este nuevo "circuito punitivo" 88 tiene importantes repercusiones procesales, dado que el reconocimiento de las personas jurídicas como sujetos activos del delito, y por ende como sujetos pasivos del proceso penal, implica su adquisición automática del estatus de imputado, lo cual obliga a repensar los derechos y garantías del imputado para adaptarlos a este nuevo sujeto pasible de pena.

3. Si se parte de que la condición de imputado, y la atribución de los derechos y garantías derivados de tal estatus, se fundamenta en la sujeción que el proceso penal supone para el sujeto enjuiciado en su seno, se concluirá inexorablemente que a la persona jurídica le corresponden todos los derechos y garantías propios del imputado, en cuanto sean compatibles con su especial naturaleza. En este sentido, y en línea de principio, el sujeto que resulta imputado, acusado y eventualmente condenado en un proceso penal ha de gozar de los derechos y garantías propios del sujeto pasivo del proceso penal, con independencia de su naturaleza ontológica.

4. Tras analizar la regulación, española y chilena, sobre los derechos procesales reconocidos a las personas jurídicas imputadas se debe concluir que la regulación chilena, contenida en una ley especial, es más exhaustiva y garantista que la espańola, contenida en la LECrim, recientemente modificada a tal efecto por la LMAP, entre otras cosas porque en la regulación de Chile se le atribuye a la persona jurídica el estatus de imputado y se le reconocen, en términos generales, los mismos derechos que a la persona física.

5. En concreto, en la regulación procesal penal española no estarían expresamente contenidos el derecho a la presunción de inocencia, la facultad del indagado de activar la investigación y la del juez de remover los obstáculos al ejercicio efectivo de su derecho de defensa, la información de derechos a la persona jurídica imputada antes de tomarle declaración o la faceta defensiva del interrogatorio de la entidad en la primera comparecencia, en la que se produce su imputación formal. La falta de reconocimiento expreso de algunos de tales derechos se puede salvar, como se ha intentado argumentar, a través de una lectura constitucional y garantista del articulado de la centenaria LECrim, a través de la cual es posible alcanzar un nivel de garantías similar en

\footnotetext{
88 Expresión acuñada por PÉrez GIL, Julio (2011). "El proceso penal contra personas jurídicas: entre lo vigente, lo proyectado y lo imaginado”. En Pérez Gil, Julio; De Román Pérez, Raquel. E. (coordinadores). Estudios juridicos sobre la empresa y los negocios: una perspectiva multidisciplinar. Burgos: Universidad de Burgos, pp. 383-406, p. 383.
} 
ambos ordenamientos. Pero, a pesar de ello, de lege ferenda se propone su reconocimiento legal y expreso en aras de reforzar la seguridad jurídica que debe informar el ordenamiento jurídico.

6. El derecho a no declarar contra uno mismo se le reconoce a la persona jurídica, tanto en la regulación chilena como en la espańola, pero mientras en la LECrim solo se permite su ejercicio al representante especialmente designado por la entidad para actuar como su representante en el proceso, en la regulación chilena se extiende a todos los representantes de la persona jurídica. En todo caso, para decidir sobre la extensión o alcance del citado derecho, será necesario buscar un equilibrio entre el derecho de autodefensa de la persona jurídica, que se ejercerá fundamentalmente a través de las declaraciones de sus representantes, y el interés público en el descubrimiento y la punición de los delitos.

7. Cuando exista una sospecha que permita atribuir, más o menos fundadamente, responsabilidad penal a una persona jurídica será necesario proceder, de forma inmediata, a su imputación formal, sin que quepa retrasar el acto de imputación en orden a avanzar en la investigación y determinar qué concretas personas físicas son autoras de los hechos punibles. Por este motivo, para el supuesto en el que una persona física, representante o empleado de una persona jurídica, deba ser imputada por algún delito de los que son susceptibles de generar responsabilidad para las personas jurídicas, el juez de instrucción deberá sopesar ad limine, por tanto sin realizar grandes indagaciones a tal efecto, la posibilidad de imputar también a la persona jurídica. Esta simultaneidad en la imputación se explica fundamentalmente en atención a dos factores concurrentes: por un lado, el juicio de mera posibilidad que requiere la imputación y por otro, la falta de criterios de imputación claros y específicos de la persona jurídica, cuya responsabilidad se fundamenta en las actuaciones delictivas de quienes actúan en su nombre.

8. En cuanto al momento adecuado para formalizar la investigación o la imputación contra la persona jurídica, la regulación chilena resulta especialmente interesante ya que obliga a ampliar la investigación a la persona jurídica, si en la indagación de algún delito imputable a una persona jurídica, se toma conocimiento de la participación de alguno de los sujetos que pueden provocar la responsabilidad del ente. Además, la propia entidad puede, en cualquier momento, pedir que se formalice la investigación en su contra para poder ser parte en el proceso y ejercitar su derecho de defensa.

9. Es necesario garantizar que la persona jurídica podrá ejercitar su derecho de defensa, incluso frente a sus administradores y representantes coimputados, para lo cual habrá de solucionarse el posible conflicto de intereses, real o potencial, que puede surgir entre la entidad y su 
representante legal, cuando este último se encuentre, asimismo, imputado. La persona jurídica normalmente constituye un conglomerado de intereses a los que el enjuiciamiento debe atender teniendo en cuenta la posible estructura policéntrica del "conflicto".

10. En cuanto a quien ha de representar a la entidad en el proceso, encarnando su defensa material y ejercitando sus facultades autodefensivas, los distintos ordenamientos ofrecen soluciones dispares. En general, se puede decir que los ordenamientos español e italiano resultan más respetuosos con la libertad interna de la empresa a la hora de nombrar un representante y configuran su designación como una carga procesal para la entidad, de tal forma que, si la misma es desatendida, se pierden las posibilidades procesales de autodefensa, sustanciándose el proceso con los abogados que encarnan la defensa técnica. Por su parte, el ordenamiento chileno, más similar al francés en este punto, no permite que la entidad designe libremente a su representante, sino que el mismo es individualizado por el Ministerio Público. Si el representante no comparece se dictará contra él orden de arresto y si, aún así, no es habido se nombrará un defensor penal público que actuará como curador ad litem.

11. En todo caso, hay que tener presente que la consideración de las personas jurídicas como un mero objeto del proceso penal y no como un verdadero sujeto del mismo, con derechos y capacidad de actuación para ejercitarlos, puede llevar a vaciar de contenido el nuevo régimen de responsabilidad penal de las personas jurídicas.

\section{Bibliografía CITADA}

- Asencio Mellado, José Ma (1993). "El imputado en el proceso penal español". En AA.VV. Cuadernos de Derecho Judicial: La restricción de los derechos fundamentales de la persona en el proceso penal. Madrid: Consejo General del Poder Judicial, pp. 61-78.

- Bacigalupo Sagesse, Silvina; Sánchez-Vera Gómez-Trelles, Yolanda (2005) Cuestiones prácticas en el ámbito de los delitos de empresa. Perspectivas de la dimensión jurisprudencial. Barcelona: Ediciones Experiencia.

- Banacloche Palao, Julio (2011) "La imputación de la persona jurídica en la fase de instrucción”. En Banacloche Palao, Julio; Zarazalejos Nieto, Jesús; Gómez-Jara Díez, Carlos. Responsabilidad penal de las personas jurídicas: aspectos sustantivos y procesales, Madrid: La Ley, pp. 155-193.

- Carbonell Mateu, Juan Carlos; Morales Prats, Fermín (2010). "Responsabilidad penal de las personas jurídicas". En Álvarez García, Francisco Javier; González Cussac, José Luis (directores), 
Comentarios a la reforma penal de 2010. Valencia: Tirant lo Blanch, pp. 55-84.

- Carnelutti, Francesco (1961) Cuestiones sobre el proceso penal. Traducción de Santiago Sentís Melendo. Buenos Aires: Ediciones jurídicas Europa-América.

- Del Moral García, Antonio. "Peculiaridades del juicio oral con personas jurídicas acusadas". En Serrano Butragueño, Ignacio; Del Moral García, Antonio (coordinadores). El juicio oral en el proceso penal. Granada: Comares, pp. 721-762.

- De la Fuente Honrubia, Fernando (2004) Las consecuencias accesorias del artículo 129 del Código Penal. Valladolid: Lex Nova.

- De la Mata Barranco, Norberto (2010). "La responsabilidad penal de las personas jurídicas". En Juanes Peces, Ángel (director) Reforma del Código Penal. Perspectiva económica tras la entrada en vigor de la Ley Orgánica 5/2010 de 22 de junio. Situación jurídico-penal del empresario, Madrid: El Derecho, pp. 67-89.

- Del Olmo Del Olmo, Juan A. (1999) Garantías y tratamiento del imputado en el proceso penal. Madrid: Trivium.

- Echarri Casi, Fermín J. (2003) Sanciones a personas jurídicas en el proceso penal: las consecuencias accesorias, Navarra: Aranzadi.

- Fernández Palma, Rosa (1995) "El terrorista arrepentido en los proyectos de Código Penal de 1992 y 1994”, Cuadernos de Política Criminal, no 57, pp. 915-931.

- Fernández Teruelo, Javier G. (2010) "Algunas consideraciones críticas sobre el nuevo modelo de responsabilidad penal de las personas jurídicas introducido en la LO 5/2010", Revista de Derecho Penal, no 31, publicado en septiembre de 2010, pp. 43-72.

- Fidelbo, Giorgio (2010), "Le atribuzioni del giudice penale e la partecipazione dell'ente al processo". En Bastia, Paolo et al. Lattanzi, Giorgio (director), Reati e responsabilità degli enti: guida al D. lgs. 8 giugno 2001, n. 231. 20 ed. Milano: Giufrè Editore, pp. 435-487.

- Fernández Teruelo, José Antonio (2010). "Algunas consideraciones críticas sobre el nuevo modelo de responsabilidad penal de las personas jurídicas introducido en la LO 5/2010", Revista de Derecho Penal, no 31, publicado en septiembre de 2010, pp. 4372.

- Gómez-Jara Díez, Carlos (2009). "La atenuación de la responsabilidad empresarial en el Anteproyecto de Código Penal de 2008: los compliance programs y la colaboración con la administración de justicia”. En Casanueva Sanz, Itziar et al. El anteproyecto de modificación del Código Penal de 2008: algunos aspectos. Bilbao: Universidad de Deusto, pp. 221-289.

- García Berro, Florián (2010) "Derecho a no autoincriminarse de los contribuyentes y procedimiento sancionador separado: 
precisiones a la luz de la evolución jurisprudencial”. En Quincena Fiscal Aranzadi, no 19. Navarra: Aranzadi, pp. 15-48.

- Gascón Ichausti, Fernando (2010) "Consecuencias procesales del nuevo régimen de responsabilidad penal de las personas jurídicas: la persona jurídica como sujeto pasivo del proceso penal". En Gascón Inchausti, Fernando (coordinador). Repercusiones sobre el Proceso penal de la LO 5/2010, de reforma del Código Penal. Navarra: Aranzadi, Thomson Reuters, pp. 19-104.

- Gimeno Sendra, Vicente (2010) Manual de Derecho Procesal Penal. $2^{\text {a }}$ ed. Madrid: Colex.

- Gómez Tomillo, Manuel (2010) Introducción a la responsabilidad penal de las personas jurídicas en el sistema español. Valladolid: Lex Nova.

- Hernández Basualto, Héctor (2010). "La introducción de la responsabilidad penal de las personas jurídicas en Chile", Politica Criminal, Vol. 5, no 9, julio 2010, pp. 207-236. Disponible en: www.politicacriminal.cl/Vol_05/n_09/Vol5N9A5.pdf

- Hernández García, Javier (2010) "Problemas alrededor del estatuto procesal de las personas jurídicas penalmente responsables", Diario La Ley, no 7427, publicado el 18 de junio de 2010. Disponible en

ht tp://p88-127.0.0.1.accedys.udc.es/accedix 0/sitios/ control/0incrustat.php?aplicacion $=10031$

- Lamarca Pérez, Carmen (1985) Tratamiento juridico del terrorismo. Madrid: Ministerio de Justicia.

- López Barja de Quiroga, Jacobo (2004) Tratado de Derecho Procesal Penal, Navarra: Aranzadi.

- López Garrido, Diego (1987) Terrorismo, politica y derecho en España, Reino Unido, República Federal de Alemania, Italia y Francia. Madrid: Alianza.

- López Yagües, Verónica (2011). “La condición de imputado en el proceso penal español. Formas de adquisición y status jurídico que conlleva. Ideas para su reforma”. En Asencio Mellado, José Ma.; Fuentes Soriano, Olga (directores); Cuadrado Salinas, Carmen (coordinadora). La reforma del proceso penal. Madrid: La Ley, pp. 20111.

- Nieto Martín, Adán (2007). “¿Americanización o europeización del derecho penal económico?", Revista Penal, Vol. 19, enero de 2007, pp. 120-136.

- Nieto Martín, Adán (2008) La responsabilidad penal de las personas juridicas: esquema de un modelo de responsabilidad penal, Madrid: Iustel.

- Nieva Fenoll, Jordi (2012) Fundamentos de Derecho procesal penal. Buenos Aires: Bdf. 
- Pérez Gil, Julio (2011). "El proceso penal contra personas jurídicas: entre lo vigente, lo proyectado y lo imaginado". En Pérez Gil, Julio; De Román Pérez, Raquel. E. (coordinadores). Estudios jurídicos sobre la empresa y los negocios: una perspectiva multidisciplinar. Burgos: Universidad de Burgos, pp. 383-406.

- Portal Manrubia, José (2010) "La persona jurídica ante la jurisdicción penal tras la última reforma del Código Penal" Revista Aranzadi Doctrinal, no 6, publicado en octubre de 2010, pp. 167182.

- Ramos Méndez, Francisco (2011) Enjuiciamiento criminal. Décima lectura constitucional, Barcelona: Atelier.

- Revilla González, José Alberto (2000) El interrogatorio del imputado, Valencia: Tirant lo Blanch.

- Rodríguez Yagüe, Carmen (2006) "La protección de los whistleblowers por el ordenamiento español: aspectos sustantivos y procesales". En Arroyo Zapatero, Luis; Nieto Martín, Adán (coordinadores), Fraude y corrupción en el Derecho penal económico europea. Eurodelitos de corrupción y fraude, Cuenca: Ediciones de la Universidad de Castilla La Mancha, pp. 447-484.

- Serra Domínguez, Manuel (1969) Estudios de Derecho Procesal. Barcelona: Ariel.

- Tomé Paule, José; García Lubén Barthe, Paloma; Tomé García, José Antonio (2010) Temario de derecho procesal penal, adaptado al nuevo programa de las pruebas selectivas para el ingreso en las carreras judicial y fiscal. $4^{\mathrm{a}} \mathrm{ed}$. Madrid: Colex.

- Viada López-Puigcerver, Carlos (1950) Lecciones de Derecho Procesal. Madrid: Alpe.

- Velasco Núnez, Eloy (2012) "Responsabilidad penal de las personas jurídicas: aspectos sustantivos y procesales", Diario La Ley, $\mathrm{n}^{\circ}$ 7883, 19 de junio 2012. Disponible en

http://p 88-127.0.0.1.accedys.udc.es/accedix0/sitios/ control/0incrustat. php?aplicacion $=10031$

- Zugaldía Espinar, José Miguel (1997). "Delitos contra el medio ambiente y responsabilidad criminal de las personas jurídicas". En Bacigalupo Zapater, Enrique (director): Cuadernos de derecho judicial (Ejemplar dedicado a Empresa y delito en el nuevo CP), no 2, Madrid: Consejo General del Poder Judicial, pp. 211-239.

- Zúñiga Rodríguez, Laura (2009) Bases para un modelo de imputación de responsabilidad penal a las personas jurídicas. $3^{\mathrm{a}}$ ed. Navarra: Thomson-Aranzadi, Cizur Menor. 